Prog Mol Biol Transl Sci. 2012 ; 107: 263-293. doi:10.1016/B978-0-12-385883-2.00004-7.

\title{
Tau and Tauopathies
}

\author{
Gloria Lee and Chad J. Leugers \\ Department of Internal Medicine, University of lowa Carver College of Medicine, lowa City, IA \\ 52242
}

\section{Abstract}

Tauopathies are age-related neurodegenerative diseases that are characterized by the presence of aggregates of abnormally phosphorylated tau. As tau was originally discovered as a microtubuleassociated protein, it has been hypothesized that neurodegeneration results from a loss of the ability of tau to associate with microtubules. However, tau has been found to have other functions aside from the promotion and stabilization of microtubule assembly. It is conceivable that such functions may be affected by the abnormal phosphorylation of tau and might have consequences for neuronal function or viability. This chapter provides an overview of tau structure, functions, and its involvement in neurodegenerative diseases.

\section{Keywords}

Tau; Alzheimer's disease; tauopathies; phosphorylation; SH3 domain; microtubule

Tau was discovered as a microtubule-associated protein from porcine brain that promoted microtubule assembly in vitro ${ }^{1}$. The tau protein sequence determined from murine cDNA was the first to be reported for a microtubule-associated protein ${ }^{2}$ and subsequently, antisense treatment of primary neuronal cultures indicated a critical role for tau in axonal development ${ }^{3}$. While studies of two independently generated tau knockout mouse models suggested that mice lacking tau appeared to develop normally, neurons cultured from one such mouse showed detectable slowing in axonal maturation ${ }^{4 ; 5}$. In addition, the defects in neuronal development exhibited by a MAP1B knockout mouse were exacerbated when tau was also deleted ${ }^{6}$. These studies underline the fact that several microtubule-associated proteins exist in the brain and suggest that each might have their own distinct functions during development and in the adult. In fact, while tau shares significant sequence homology with microtubule-associated proteins MAP2 and MAP4 in the carboxyl terminus microtubule binding domain, it shares very little homology in the amino terminal "projection domain" $7 ; 8$.

The idea that different microtubule-associated proteins each have distinct functions is clearly illustrated by the fact that only tau has been associated with neurofibrillary tangles in agerelated neurodegenerative diseases such as Alzheimer's disease (AD) $9 ; 10 ; 11$. Moreover, mutations in the tau gene, MAPT, cause autosomal dominant neurodegenerative diseases such as frontotemporal dementia with Parkinsonism linked to chromosome $17^{12 ; 13 ; 14}$, and transgenic mouse models expressing mutant tau exhibit neuronal loss (reviewed by $15 ; 16 ; 17 ; 18$ ). A mechanistic understanding of the route by which tau leads to neurodegeneration is still unclear. However, alongside hypotheses based on the loss of tau's ability to stabilize microtubules are other possibilities based on new functions and interactions that have been described for tau. This chapter will summarize recent studies on 
the interaction of tau with microtubules in addition to investigations indicating that the function of tau extends beyond its actions on microtubules. Much like its microtubulebinding properties, these alternative functions of tau may be regulated by phosphorylation. Therefore, such functions might be altered in the disease state where tau is abnormally phosphorylated and play a role in neuropathological processes.

\section{Tau gene and isoforms}

Tau is encoded by a single gene, MAPT, located on chromosome $17 \mathrm{q} 21^{19}$. MAPT is over $50 \mathrm{~kb}$ in size and comprises two haplotypes, $\mathrm{H} 1$ and $\mathrm{H} 2$, with multiple variants of each $20 ; 21$. Several tau isoforms are generated by alternative splicing, creating both high and low molecular weight isoforms. The human central nervous system expresses six low molecular-weight isoforms that range in size from 352 to 441 amino acids (Fig. 1). These isoforms are differentiated by the presence or absence of sequences encoded by MAPT exons 2,3 , and $10^{22}$. Exons 9, 10, 11, and 12 each encode a microtubule binding motif. The four motifs are imperfect copies of an 18 amino acid sequence termed a "repeat," and each repeat is separated by a $13-14$ amino acid inter-repeat sequence ${ }^{2}$. Isoforms that include exon 10 are commonly referred to as four-repeat or $4 \mathrm{R}$ tau isoforms while those that exclude exon 10 are referred to as three-repeat or 3R tau isoforms. Alternative splicing of tau is developmentally regulated, with exons 2,3 , and 10 being expressed only post-natally 22 . Human adult tau has approximately equal representation of $3 R$ and $4 R$ tau isoforms, with the $1 \mathrm{~N} 3 \mathrm{R}$ and $1 \mathrm{~N} 4 \mathrm{R}$ being the most abundant forms ${ }^{23 ; 24}$. Alternative splicing of human tau differs from that of rodent tau, as adult rodent tau is predominantly $4 \mathrm{R}$ tau ${ }^{25}$. Comparison of the tau sequence from mouse, rat, cow, monkey, goat, and chicken shows high conservation of the microtubule binding repeats across species $2 ; 25 ; 26 ; 27 ; 28$. Tau-like sequences have also been found in frog, nematode, and zebrafish $29 ; 30 ; 31$.

Because 4R tau isoforms contain a fourth microtubule binding repeat, adult tau interacts with microtubules more strongly $32 ; 33 ; 34$. Tau alternative splicing can also affect its phosphorylation, which influences the interaction between tau and microtubules ${ }^{35}$. Phosphorylation is generally higher in fetal tau ${ }^{36}$. When a single tau cDNA is expressed by transfection in cells, several differentially phosphorylated species can be generated.

While mice with a disrupted tau gene are viable, microarray analysis performed on the brains of such mice showed alterations in gene expression relative to wild type mice ${ }^{37}$. The genes with the highest levels of change did not involve the cytoskeleton, suggesting that the most critical function of tau may not be related to microtubule binding. For example, adult tau knockout mice had increased muscle weakness ${ }^{38}$ and were protected against experimentally induced seizures ${ }^{39}$. The idea that tau might play a role in processes other than axonal development is supported by the fact that tau is expressed in non-neuronal cells. Tau expression has been reported in muscle, liver, kidney, and other tissues ${ }^{40 ; 41}$. It has also been found in human breast, prostate, gastric, and pancreatic cancer cell lines and tissues $42 ; 43 ; 44 ; 45 ; 46$, as well as in the muscle cells of individuals with inclusion body myositis ${ }^{47}$. The function of tau in non-neuronal cells remains to be elucidated and functions outside of the cytoskeleton may have significance for neurodegenerative disease.

\section{Tau in neurodegenerative disease}

While the discovery of tau predated its connection to $\mathrm{AD}$, its importance in neurodegenerative disease has attracted a large community of investigators. $\mathrm{AD}$ is characterized by two neuropathological features, senile plaques and neurofibrillary tangles, and tau is the primary component of the neurofibrillary tangles (NFT, reviewed by ${ }^{48 ; 49}$ ). Senile plaques are made of amyloid $\beta$-protein $(A \beta)$ and the gene encoding $A \beta$ has been connected to $\mathrm{AD}$ (reviewed by ${ }^{50}$ ). However, $M A P T$ has not been genetically linked to $\mathrm{AD}$. 
Nevertheless, cultured neurons exposed to $A \beta$ do not undergo cell death in the absence of tau ${ }^{51}$. Likewise, genetically removing tau from animal models that exhibited amyloid plaques lessened the deficits induced by the amyloid ${ }^{39}$. These findings underline a critical role for tau in the neurodegenerative process. Moreover, tau pathology is found in several other age-related neurodegenerative diseases such as progressive supranuclear palsy (PSP), corticobasal degeneration (CBD), Pick's disease, argyrophilic grain disease (AGD), and frontotemporal dementia. Tau pathology involving 4R tau is found in PSP, CBD, and AGD, with tau aggregates being found in the medial temporal lobe, cortex, basal ganglia, subthalamic nucleus, and substantia nigra. Besides neurons, oligodendrocytes and astrocytes can also display tau pathology. Pick's disease has 3R tau in the Pick bodies that are found in the hippocampus and dentate fascia. The clinical presentation of these diseases includes dementia, Parkinsonism, and focal cortical syndrome (reviewed by $52 ; 53 ; 54 ; 55$ ).

The importance of tau in neurodegeneration has been verified by the discovery of MAPT mutations in families with frontotemporal dementia with Parkinsonism linked to chromosome 17 (FTDP-17; reviewed by $56 ; 57 ; 58$ ). Mutations in the tau gene are responsible for $\approx 30 \%$ of inherited FTD. These mutations are autosomal dominant and can be located in either coding or non-coding regions. More than $90 \%$ of the mutations in coding regions are located in the carboxyl terminal end of tau, with P301L being the most prevalent (Table 1). Mutations in non-coding regions are mainly within the intron separating exons 10 and 11 . These mutations modulate alternative splicing of the MAPT mRNA, resulting in higher than normal levels of $4 \mathrm{R}$ tau relative to $3 \mathrm{R}$ tau ${ }^{59}$. In addition, the tau haplotype $\mathrm{H} 1 \mathrm{c}$ has been linked to progressive supranuclear palsy $21 ; 60$.

\section{Tauopathy models}

Transgenic animals expressing mutant tau cDNAs exhibit tau pathology that increases with age. While these models have shown a variety of traits, perhaps owing to the variety of mutations and gene promoters employed, a striking feature has been neuronal loss and behavioral deficits (reviewed by 16;17;61). Mouse models expressing only mutant genes involved in amyloid production showed amyloid plaques, but did not acquire neurofibrillary tangles or suffer neuronal loss ${ }^{62}$. Therefore, inclusion of a mutant tau cDNA in addition to mutant genes involved in amyloid production was integral in creating a triple transgenic mouse model that exhibited both the plaques and tangles characteristic of $\mathrm{AD}^{63}$.

Cell culture models that reproduce tau filament formation have been reported ${ }^{64 ; 65}$. However, the polymerization of $E$. coli-synthesized tau in vitro, induced by either arachidonic acid or heparin, has enabled a more extensive analysis of the structural features of tau that are involved in polymerization (reviewed by $66 ; 67 ; 68$ ). These studies have led to the identification of specific motifs in the tau repeat region that facilitate the formation of tau filaments ${ }^{69}$. In such assays, FTDP-17-associated missense mutations or tau truncation at Asp421 increased filament formation $70 ; 71 ; 72$. These results suggest that filament formation in the human neuroblastoma cell culture model may have involved the cleavage of tau at Asp421, as conversion of the neighboring Ser422 to Ala or Glu led to a loss of filament formation in cells ${ }^{64}$. Lastly, the in vitro assays have indicated that several phosphomimicking mutations slowed filament formation $73 ; 74 ; 75$, although some facilitated formation ${ }^{76}$.

Despite the evidence that tau filaments are a hallmark feature of classic AD pathology, some models hint at the possibility that tau filaments may not be a prerequisite for neurodegeneration. Studies of a mouse model with inducible tau expression have shown that down-regulation of tau expression, without a decrease in tangle burden, was sufficient to ameliorate behavioral deficits ${ }^{77}$. Moreover, tauopathy mouse models exist where behavioral deficits were exhibited without the presence of tangles or neuronal loss ${ }^{78 ; 79}$. In addition, in 
Drosophila and nematode tauopathy models, neuronal loss and behavioral deficits occurred without the formation of tau filaments $80 ; 81$. Taken together, these studies have suggested that tau, in its soluble form, may have unidentified roles in the mechanisms underlying both neuronal cell function and disease. Tau oligomers that occur in advance of tau filaments have been proposed as a critical entity in the neurodegenerative process (reviewed by ${ }^{82}$ ). These observations, in combination with other recent studies, have raised the possibility that tau filament formation may be a protective mechanism initiated by cells to sequester abnormal tau (reviewed by $83 ; 84 ; 85$ ).

In neurodegenerative disease, the phosphorylation state of tau in NFTs and other tau lesions is abnormal, meaning that there is an increase in both the overall number of sites phosphorylated and the level of phosphorylation at particular sites relative to normal adult brain tau. Tau phosphorylation is complex. The 441 residue tau protein has $45 \mathrm{Ser}, 35 \mathrm{Thr}$, and 5 Tyr residues, presenting a multitude of phosphorylation sites. In addition, phosphorylation at some sites facilitates the subsequent phosphorylation of other sites. The effect of phosphorylation depends on the location of the site modified (See Section IV below). Both kinases and phosphatases have been implicated in the appearance of abnormally phosphorylated tau, and despite differences in the morphology of tau lesions among tauopathies, abnormal tau phosphorylation is a common denominator. Interestingly, many sites that are phosphorylated in disease correspond to sites that are phosphorylated during normal brain development $86 ; 87 ; 88$. The regulation of tau phosphorylation and tau kinases in both development and disease, as well as the functional significance of tau phosphorylation, has been the subject of much investigation. Because of the prevalence of abnormal tau phosphorylation during neurodegeneration, reducing tau phosphorylation as a therapeutic strategy has been investigated (reviewed by ${ }^{89 ; 90}$ ). A significant challenge has been limiting the action of kinase inhibitors to tau phosphorylation.

The abnormal phosphorylation of tau also occurred in tau transgenic mouse models that express either FTDP-17 mutant or wild type tau (reviewed by ${ }^{91}$ ) and reducing tau phosphorylation in one such model lessened aggregated tau and axonal degeneration 92 . Experiments in Drosophila tauopathy models have demonstrated that tau phosphorylation is required for neuronal loss 93 . This same study also showed that cell cycle genes were required for tau-induced neurodegeneration, supporting the hypothesis that neurons die because they are receiving signals to divide (reviewed by $94 ; 95$ ). The presence of "mitotic" phospho-epitopes in "disease tau", characteristic of the tau expressed during development, had first led to this hypothesis $96 ; 97 ; 98 ; 99$ and the presence of tetraploid neurons in AD brain has strengthened the hypothesis ${ }^{100}$.

\section{Interactions with the cytoskeleton}

\section{Microtubule binding and assembly}

Tau was originally discovered through its ability to promote microtubule assembly, which stems from its ability to modulate the dynamic instability of microtubules $33 ; 101$. The interaction between tau and microtubules depends on the tau microtubule-binding repeats, as well as on the flanking regions upstream and downstream of the repeats. Defining the role of the flanking regions was largely accomplished by investigating the ability of truncated or point-mutated tau proteins to either associate with microtubules $102 ; 103 ; 104 ; 105$ or to decrease dynamic instability ${ }^{33}$.

Most recently, the physical interaction between tau and microtubules has been delineated using nuclear magnetic resonance spectroscopy (NMR). Comparison of the NMR spectra of tau in the presence and absence of microtubules indicated that while all repeats contacted the microtubules, there were specific sequences that were strongly involved in the 
interaction ${ }^{34 ;} 106$. These sequences included ${ }^{240} \mathrm{KSRLQTAPV}^{248},{ }^{275}$ VQIINKKLDLS ${ }^{285}$, and ${ }^{297} \mathrm{IKHV}^{300}$. In addition, residues in the flanking regions as far upstream as Ser214 and as far downstream as Lys375 were also involved ${ }^{107}$, with ${ }^{225}$ KVAVVRT $^{231}$

and ${ }^{370}$ KIETHK $^{375}$ having especially strong interactions ${ }^{34}$. These data indicate that in the presence of microtubules, the molecular environment around the tau regions flanking the microtubule repeats changed. Although the simplest explanation is that a direct interaction occurred between these tau areas and the microtubule, one cannot rule out the possibility that flanking regions were involved in intramolecular interactions and that in the presence of microtubules, such interactions were altered ${ }^{108}$.

${ }^{275}$ VQIINKKLDLS ${ }^{285}$ and ${ }^{297}$ IKHV $^{300}$ are both in exon 10, a fact that may explain why $4 \mathrm{R}$ tau isoforms interact with microtubules more strongly than do $3 \mathrm{R}$ tau isoforms. Interestingly, in comparing $4 \mathrm{R}$ and $3 \mathrm{R}$ tau, it has been found that $4 \mathrm{R}$ tau could decrease microtubule shortening during dynamic fluctuations in microtubule length whereas $3 R$ tau had no effect in this regard ${ }^{109}$. In addition, $4 \mathrm{R}$ tau and $3 \mathrm{R}$ tau showed qualitative differences with respect to their actions on the microtubule growth rate and on the behavior of growing microtubule populations ${ }^{110}$. These differences have significance towards both the function of microtubules over the course of development and the consequences of the change in the 4R:3R tau ratio brought on by intronic tau mutations. Lastly, the binding of tau to microtubules has been visualized by cryo-EM, showing that tau bound along individual protofilaments ${ }^{111}$. Synchrotron $\mathrm{x}$-ray scattering data has suggested that tau altered the shape of the protofilament, resulting in changes in the curvature of microtubules and a shift from 13 to 14 microtubules per protofilament ${ }^{112}$.

Several studies have demonstrated that some FTDP-17 missense mutations reduced the ability of tau to promote microtubule assembly $24 ; 113 ; 114 ; 115$. Additional insights have been gained through NMR data ${ }^{116}$, analysis of microtubule dynamics in cells ${ }^{117}$, and experiments utilizing Xenopus oocytes to assess microtubule function ${ }^{118}$. While these investigations have shown that some mutations attenuated the ability of tau to bind to microtubules and to regulate the dynamic instability of microtubules, missense mutations outside of the microtubule repeat region did not replicate these effects, suggesting that different FTDP-linked tau mutations affect tau function in different ways.

The interaction between tau and microtubules is greatly decreased by tau phosphorylation at Ser262 and Ser356, and phospho-mimicking replacements at these positions effectively reduce microtubule association in vitro and in cells ${ }^{119}$. Other phosphorylation sites shown to have some effects on microtubule association are Ser205, Ser212, Ser214, Thr231, Ser235, Ser396, and Ser 404 33; 75; 98; 120;121; 122. On tubulin, the tau-interacting site is located at the carboxyl terminal end, which is highly acidic. Therefore, the interaction between the basic tau repeat regions and microtubules is thought to be primarily electrostatic in nature. This is consistent with the ability of salt to affect the binding between tau and microtubules. Thus, it is not surprising that the addition of an acidic phosphate group to tau would attenuate its association with microtubules, provided the location of the phosphate was appropriate. A reduction in the microtubule-binding or assembly-promoting ability of tau has been a recurrent theme in hypotheses regarding the role of hyperphosphorylation in mechanisms of neurodegeneration (reviewed by ${ }^{123}$ ). As a result, development of therapeutics aimed at preserving microtubules has been undertaken (for instance, see ${ }^{124}$ ).

\section{Axonal transport}

Fast axonal transport (FAT) is significantly impaired in a number of neurodegenerative diseases, including tauopathies, and these defects have been linked to alterations in the normal function of tau (reviewed in ${ }^{125}$ ). For example, in cellular models where tau was over-expressed, a disruption in the trafficking of membranous vesicles and mitochondria 
was found $126 ; 127 ; 128 ; 129 ; 130$. Similarly, various mouse models of tauopathy where wild type or mutant tau was expressed also demonstrated impaired axonal transport $131 ; 132$. The ability of tau to interfere with axonal transport may arise through direct interactions between tau and transport motor complexes. In fact, tau was able to associate with kinesin as demonstrated by immunofluorescence and co-immunoprecipitation experiments 133 ; 134 . In vitro experiments have further identified a direct interaction between tau and kinesin 135; 136 , and between tau and the p150 protein in the dynein-dynactin motor complex ${ }^{137}$. Moreover, these direct interactions between tau and motors decreased the ability of kinesin to attach to microtubules 138 and increased the rate of motor detachment from microtubules 139; 140, although the above studies also reported conflicting data concerning whether tau altered overall cargo transport rates. As these results have shown, the effects of tau on axonal transport may be more complex than simply blocking motor access to the microtubules. For instance, an interaction between tau and c-Jun N-terminal kinase-interacting protein 1 (JIP1) has been proposed to affect the kinesin-I motor complex, causing a re-localization of JIP1 and impaired axonal transport ${ }^{141}$. Also, in Aplysia, tau overexpression was capable of causing both a complete stop in transport and a reorganization of microtubule polarity within the axon ${ }^{142}$. The conformation of tau may influence FAT as well since studies performed using squid axoplasm showed that soluble, monomeric tau did not affect transport ${ }^{143}$ whereas tau filaments or N-terminal fragments significantly reduced transport using a mechanism involving PP1, GSK-3 $\beta$ and the light chain of the kinesin motor ${ }^{144}$.

In spite of the abundance of data that has implicated tau in the inhibition of FAT, a study showing similar rates of axonal transport in wild type, tau transgenic, and tau depleted mice has argued against the ability of tau to significantly affect this process ${ }^{145}$. These discrepancies may originate from differences in tau phosphorylation between the experimental systems, differences in the experimental methods used to measure FAT, or differences in the cellular sources used. Further studies are needed to clarify the role of tau in the inhibition of FAT in neurodegenerative diseases.

\section{Interactions with actin}

Shortly after it was reported as a microtubule-associated protein, tau was also found to associate with actin in vitro $146 ; 147$. The interaction site was subsequently mapped to the microtubule binding domain, and then specifically to the repeats ${ }^{148 ; 149}$. The functional implications of this interaction have remained obscure, although tau depletion in cultured neurons altered actin morphology in growth cones ${ }^{150}$ and inactivation of tau in the growth cones caused collapse of lamellipodia ${ }^{151}$. More recently, the C-terminus of tau was found to co-localize with actin in the growing neurite tips of NGF-differentiated PC12 cells ${ }^{152}$. Nevertheless, E. coli tau failed to bind to actin in vitro ${ }^{153}$, suggesting that these previously reported associations might require specific tau phosphorylation or involve intermediates. An association with actin may explain why tau phosphorylated on Ser262, a modification that decreases the affinity of tau for microtubules, had a role in neurite outgrowth $119 ; 154$. Other reports have suggested that tau may affect actin remodeling indirectly. Tau expression antagonized the action of Gem GTPase, a negative regulator of Rho ${ }^{37}$. Rho activation is critical for neurite outgrowth, therefore tau could affect neurite outgrowth by lessening the inhibition of Rho by Gem GTPase. In addition, in fibroblasts treated with platelet-derived growth factor, tau expression delayed actin stress fiber recovery, wherein tau-expressing cells maintained the "high Rac, low Rho" actin morphology characteristic of activated cells ${ }^{155}$. Given the many interactions that have been described for tau (see Section V), as well as its known localization in the axonal growth cone $156 ; 157$, it is probable that tau has a role in orchestrating actin remodeling in response to signaling during neurite outgrowth.

An interaction between tau and actin has also been described in animal models of tauopathy. Actin aggregates analogous to Hirano bodies were found when human mutant tau was 
expressed in Drosophila and actin aggregates were also identified in mouse tauopathy models ${ }^{158}$. Moreover, actin and actin-related proteins appear in the neuropathology of Alzheimer's disease ${ }^{159}$.

\section{Phosphorylation and other post-translational modifications}

The phosphorylation of tau on serines and threonines is developmentally regulated. Table 2 lists the phosphorylated residues that have been identified in fetal and adult rat tau either by mass spectrometry $36 ; 160$ or by phospho-specific antibody probes $98 ; 161 ; 162$. These experiments demonstrate that fetal tau is more highly phosphorylated than adult tau. The phosphorylation of tau in $\mathrm{AD}$ includes all of the sites shown in Table $2{ }^{160 ; 161}$. Table 3 lists some commonly used tau antibodies, several of which detect specific phosphorylated sites. In $\mathrm{AD}$, tau is phosphorylated either at sites that are not normally phosphorylated in adult tau or at a higher level at sites that are normally phosphorylated in adult tau.

The phosphorylation of tau causes conformational changes that result in a slowing of its electrophoretic migration, and early structural studies found that tau became more elongated upon phosphorylation ${ }^{163}$. Fluorescence resonance energy transfer studies have suggested that tau normally exists in a conformation in which both the amino and carboxyl termini fold inward. This allowed the carboxyl terminus to simultaneously interact with both the microtubule repeat domain and the amino terminus ${ }^{108}$. Phosphomimicking mutations altered this conformation and generated reactivity to a conformation-specific tau antibody ${ }^{164}$. Such conformational changes may underlie the effects of tau phosphorylation on its interactions with other proteins. Phosphorylation of tau could also affect its proteolytic cleavage ${ }^{165}$.

Several Ser/Thr kinases act on tau (recently reviewed by ${ }^{49}$ ). Among the best studied are the proline-directed kinases GSK3 $\beta$, cdk5, MAPK (ERK), JNK (SAPK), and p38. Non-proline directed kinases MARK, casein kinase I (CKI), PKA, CaMKII, and PKC also phosphorylate tau. In some cases, tau phosphorylation at one site facilitated phosphorylation at another site, known as "priming." This has been demonstrated by the requirement of cdk5- or GSK3 $\beta$ mediated phosphorylation of residue Ser235 prior to phosphorylation of Thr231 by GSK $3 \beta^{122 ; 166}$. FTDP-17 mutations also promoted phosphorylation in vitro ${ }^{167}$. Many studies have been performed either in vitro with purified kinases or brain extracts, or in transfected cells where both tau and kinases were overexpressed. A significant challenge, though not unique to tau, has been to identify the kinases that are responsible for the phosphorylation of the endogenous protein in neuronal cells.

The regulation of tau phosphorylation during development is of significant interest as several of the sites phosphorylated in disease appear normally during early development. In neuroblastoma cells, Ser214 and Ser262, in addition to several proline directed sites such as Ser202, Thr205, Thr231, Ser235, Ser396, and Ser404 become highly phosphorylated during mitosis $96 ; 97 ; 98$. These findings suggest that in developing neurons, tau phosphorylation can be regulated by cell cycle mechanisms. Changes in tau phosphorylation occurring when neuronal cells were treated with $A \beta$ also have been investigated ${ }^{168}$. These findings have implicated both GSK3 $\beta$ and MAPK ${ }^{169 ; 170}$ as kinases involved in the abnormal phosphorylation of tau during AD pathogenesis. The phosphorylation of tau has also been investigated in mouse models of tauopathy as well as in mouse models where kinases or phosphatases were expressed (reviewed by ${ }^{91}$ ).

Phosphatases also act on tau, and phosphatase inhibition has been suggested as one mechanism by which tau acquires its hyperphosphorylated state during the neurodegenerative process ${ }^{171}$. Both PP1 and PP2A associate with and dephosphorylate tau $172 ; 173 ; 174 ; 175$, with PP2A accounting for $70 \%$ of the tau phosphatase activity in 
brain ${ }^{176}$. FTDP-17 mutations reduced the interaction between PP2A and tau, suggesting another route by which these mutations would result in hyperphosphorylation and disease ${ }^{177}$.

Tau contains five potential sites for tyrosine phosphorylation and Src family tyrosine kinases (Fyn, Src, and Lck), Syk, Abl, and tau-tubulin kinase phosphorylate tau. Direct interactions between tau and the SH3 domains of Fyn, Src, and Lck have been demonstrated ${ }^{178}$, and tau also interacts with Abl and Syk ${ }^{179 ;} 180$. Fyn, Src, and Syk phosphorylate tau at Tyr18 180; 181, while Abl phosphorylates Tyr394 ${ }^{179}$. Phosphorylated Tyr18 and Tyr394 have been found in early development, in tauopathy mouse models, and in AD brain, reproducing the behavior seen with disease-related Ser/Thr phosphorylated sites 179; 181; 182; 183. Phospho-Tyr197, a modification that can be generated by tau tubulin kinase ${ }^{184}$, has been identified along with phospho-Tyr394 in the tau filaments isolated from a tauopathy mouse model. It also occurs in AD brain ${ }^{182}$. The phosphorylation of tyr 29 by Lck has also been reported ${ }^{185}$. Functional implications for the tyrosine phosphorylation of tau have yet to be elucidated. However, the presence of these modifications in tau pathology, and data implicating Fyn in $\mathrm{AD}$ 186; 187; 188 , suggests that activated tyrosine kinases will also be a part of the neuropathogenic process.

In addition to being phosphorylated, tau can be O-GlcNAcylated, nitrated, and ubiquitinated. Because O-linked GlcNAcylation of tau occurs on Ser and Thr residues ${ }^{189}$, it has the potential to indirectly regulate tau phosphorylation ${ }^{190}$. Tau nitration on Tyr 29 has been found in $\mathrm{AD}$ and other tauopathies ${ }^{191}$, and the presence of nitration, which is catalyzed by reactive nitrogen species, is consistent with an elevation of oxidative stress during neurodegeneration. Ubiquitination of tau is readily seen following co-transfection of tau and the E3 ubiquitin ligase CHIP (carboxy terminus of Hsp70-interacting protein) into nonneuronal cells 192; 193; 194. The presence of ubiquitinated tau is well established in AD 195 and the specific lysines modified in abnormal tau from AD brain have been identified as Lys254, Lys311, and Lys353 ${ }^{196}$. Ubiquitination of tau has been shown to increase soluble tau levels, and to target tau for proteasomal degradation 192; 193; 197. Tau can also undergo sumoylation, a ubiquitin-like modification, at Lys340 ${ }^{198}$.

\section{Other interactions}

\section{Phospho-serine/threonine-based interactions}

Tau interacts with Pin1, a prolyl-isomerase that changes the conformation of phospho-Ser/ Thr-pro bonds from cis to trans conformation. This interaction was initially shown to involve the WW domain of pin1 that recognizes phospho-Ser/Thr residues, and the phosphoThr231 residue of tau ${ }^{199}$. Subsequently, an interaction between pin1 and the phospho$\mathrm{Thr} 212$ residue of tau was also uncovered by NMR ${ }^{200}$. The presence of pin 1 restored microtubule-polymerizing properties to tau lost following cdc2-mediated phosphorylation ${ }^{199}$ and reduced the levels of tau phosphorylation in tau transgenic mice $^{201 ; 202}$. These observations have been attributed to an increase in the susceptibility of tau to phosphatases in the presence of pin $1203 ; 204$. The opposing effects of pin1 on wildtype versus FTDP-17 mutant tau has presented more evidence for the potential importance of the interaction $201 ; 202$. Also contributing to the interest in the pin1-tau interaction is the finding that the pin1-knockout mice exhibited age-dependent neurodegeneration, increased tau phosphorylation, and neuropathology 204 .

14-3-3 is a signal transduction protein that exists in several isoforms, of which the 14-3-3 $\zeta$ isoform has been identified as a tau interactor ${ }^{205}$. 14-3-3 $\zeta$ has been shown to increase PKAmediated tau phosphorylation 205; 206 , while its effect on GSK3 $\beta$-mediated tau phosphorylation is less clear $207 ; 208 ; 209$. The phospho-Ser214 residue on tau is thought to 
be the primary binding site for $14-3-3 \zeta^{210}$, with the added presence of phospho-Ser235 strengthening the interaction ${ }^{211}$. While the impact of $14-3-3 \zeta$ on tau phosphorylation in neuronal cells remains to be investigated, evidence that the interaction is influenced by both the phosphorylation state and the isoform of tau ${ }^{212}$ suggests that the interaction could potentially have implications for both development and disease.

Tau is able to enhance growth factor-induced MAPK signaling through a mechanism that required the phosphorylation of tau at Thr231 ${ }^{213}$. Tau was phosphorylated on Thr231 in response to nerve growth factor (NGF) and tau depletion attenuated MAPK activation as well as AP-1 activation ${ }^{213}$. The effect of tau on signaling was independent of an interaction between tau and microtubules. Interestingly, these findings may have significant implications for the role of tau in neurodegenerative disease as the early appearance of phospho-Thr231-tau 214; 215 , as well as an abnormal activation of MAPK, occurs in $\mathrm{AD}^{216 ; 217 ; 218}$. One could speculate that abnormal MAPK signaling induced by various upstream triggers such as $A \beta$ accumulation, oxidative stress, and aberrant growth factor activity, would be potentiated by hyperphosphorylated tau, leading to a positive feedback loop where MAPK would phosphorylate tau further. Faulty MAPK signaling might also drive the cell cycle and culminate in neuronal cell death.

\section{SH3 domain interactions}

Within tau exons 7 and 9, upstream of the first microtubule-binding repeat, lies a prolinerich domain containing $>20 \%$ proline. This region contains seven PXXP motifs that can potentially interact with the Src homology 3 (SH3) domains commonly found in tyrosine kinases and adapter proteins. In vitro binding assays have demonstrated that a PXXP in tau interacted with the SH3 domain of Src family kinases ${ }^{178}$ and tau also interacted with the SH3 domains of phosphatidylinositol-3 kinase (PI3K), grb2, and phospholipase $\mathrm{C} \gamma$ $\operatorname{PLC} \gamma)^{219}$. Co-immunoprecipitation experiments have confirmed that tau interacted with Fyn, PI3K and PLC $\gamma$ in cells $43 ; 178 ; 220$. A possible functional significance of the tau-Fyn interaction is the upregulation of Fyn kinase activity by tau ${ }^{155}$, a known consequence of SH3 domain interactions for Src family tyrosine kinases. The presence of tau also increased PLC $\gamma$ activity, though the involvement of the SH3 domain interaction has not been demonstrated ${ }^{221}$. The involvement of the tau-Fyn SH3 interaction in directing the tyrosine phosphorylation of tau has been shown ${ }^{222}$.

Tau phosphorylation affects SH3 domain interactions $219 ; 222 ; 223$, leading to the speculation that these interactions are regulated during development and may have a role in disease. The finding that FTDP-17 tau mutations increased the tau-Fyn SH3 interaction ${ }^{222}$ also supports a role for the interaction during neuropathogenesis.

\section{Molecular chaperone interactions}

Tau interacts with both the stress induced heat shock protein hsp70 and the constitutively expressed heat shock cognate protein hsc $70{ }^{193 ; 224 ; 225}$. Both interactions promote the ubiquitination of tau by CHIP and the proteasome-mediated degradation of tau 192; 193; 194; 197; 225. The interaction with heat shock proteins may also have a role in the degradation of tau via the autophagy-lysosomal pathway 226; 227 . Previous studies have demonstrated that phosphorylation of tau increased both its ubiquitination ${ }^{193}$ and its degradation ${ }^{228}$. In addition, hsp27 and hsp90 recognize phosphorylated tau and facilitate its proteasome-mediated degradation $193 ; 229$. These results raise the possibility that, in response to disease-related phosphorylation modifications, the cell attempts to eliminate tau by a mechanism involving interactions with heat-shock proteins. 
The tau motifs that bind to hsc70 and hsp70 have been identified and correspond to the VQI(I/V) sequences in exons 9 and $10^{224}$, the motifs that have been found to mediate the $\beta$ sheet conformation involved in tau filament formation ${ }^{69}$. Therefore, in addition to potentially directing the degradation of disease tau, the association between hsc70/hsp70 and tau could also be neuroprotective by preventing tau filament formation. The ability of hsp70 to inhibit tau filament formation in vitro supports this possibility 230 .

\section{Non-microtubule localizations for tau}

Given that certain tau modifications result in a reduced affinity for microtubules, one would predict that non-microtubule localizations for tau exist. In fact, the association of tau with two non-microtubule structures within cells, the nucleoli and polysomes $231 ; 232 ; 233$, has long been known. Phosphorylation has been proposed to regulate the localization of tau to the nucleus ${ }^{234}$ and the direct association of tau with nucleic acid in vitro has also been reported ${ }^{235}$. It has recently been suggested that tau may contribute to chromosome instability 236 .

Tau that is phosphorylated at Thr231 associated with the microtubule-organizing center ${ }^{122}$ and tau that is dephosphorylated at Ser199/Ser202, Ser396/Ser404, or Thr231 associated with the plasma membrane 156; 237; 238 . Tau dephosphorylated at Ser199/Ser202 was also enriched in the growth cone of primary cultured neurons ${ }^{156 ; 239}$. Moreover, tau associated with lipid rafts, membrane microdomains implicated in signal transduction and growth cone function $240 ; 241 ; 242 ; 243$. Evidence indicating that tau-Fyn complexes existed in lipid rafts has also been reported ${ }^{240}$.

The existence of extracellular tau has been recently reported, with the amino terminus being critical for the extracellular localization ${ }^{244}$. Also, an interaction between extracellular tau and muscarinic M1 and M3 receptors has been reported, suggesting that extracellular tau is capable of inducing changes in intracellular calcium ${ }^{245}$. These findings raise the possibility that interneuronal propagation of neurodegenerative disease may involve extracellular tau. The ability of extracellular tau to induce pathology has been explored in mouse and cell culture models $246 ; 247$.

\section{Amino terminus of tau}

Investigations into the properties of truncated tau, terminating in exon 9, have revealed that the amino terminus of tau was capable of associating with the plasma membrane and affecting NGF-mediated neurite outgrowth ${ }^{156}$. Similarly, the amino terminus of tau negatively affected neurite outgrowth in oligodendrocytes ${ }^{248}$. Interestingly, the amino terminus of tau participated in $\mathrm{A} \beta$-oligomer-activated signal transduction pathways where microtubules were disrupted ${ }^{249}$. Because the truncated tau used in these studies contained the proline rich region, it is conceivable that interactions with proteins such as Src family tyrosine kinases or PI3K may underlie these reported effects. Moreover, by expressing the amino terminus of tau in mice, it has been demonstrated that the localization of Fyn was shifted from the postsynaptic area to the cell soma, due to its interaction with the amino terminus of tau in the soma ${ }^{250}$. As a result, the association of the NMDA receptor with the postsynaptic density was reduced and susceptibility to seizure was also reduced. These data strongly argue for the amino terminus having critical functions in the neuron. Moreover, the expression of the amino terminus of tau was able to lessen the deficits of an APP transgenic mouse model, similar to that achieved when $\mathrm{a} \mathrm{tau}^{-/-}$trait was introduced ${ }^{39 ; 250}$.

As a separate consideration, alternative splicing of tau is capable of generating an amino terminal fragment of tau, owing to alternative splice sites in exon 6 that create frameshifts and stop codons ${ }^{251}$. Such tau fragments inhibited fast axonal transport ${ }^{144}$. In addition, a 
toxic amino terminal fragment of tau, generated by calpain cleavage, has been described in neurons treated with $A \beta^{252}$. The production of this fragment increased in aged primary neuronal cultures and decreased if membrane cholesterol was lowered ${ }^{253}$. Taken together, these observations provide more evidence that non-microtubule-associated tau plays an important role in both normal and diseased cells.

\section{Reflections}

The idea that tau is more than a microtubule-associated protein is borne out by the fact that tau exists in forms that do not associate with microtubules and interact with many other proteins besides microtubules. And although tau knockout mice do not exhibit gross defects in brain development, their blunted response to excitotoxic stimuli suggest that tau is important for neuronal function in ways that are not yet understood. In fact, the two genes whose expression was increased the most in tau knockout mouse neurons were c-fos and fosB (Data supplement ${ }^{37}$ ), transcription factors critical for regulating transcription of a diverse range of genes. Such data strongly suggests that tau has a critical role in basic cell growth. It is not possible at present to determine whether this role stems from a function in neuronal or non-neuronal cells.

Three-dimensional structural information for tau would greatly contribute to the understanding of phosphorylation and protein conformation in tau function and the effect of FTDP-17 missense mutations and alternative splicing on tau structure. Because tau has unusual physical properties, obtaining structural data has been challenging. Recent analyses of tau using NMR indicates its potential to provide more information about tau structure ${ }^{254}$.

The ability of tau to interact with a number of signal transduction proteins suggests a possible role for tau in signaling. Tau may participate in the mTor and JNK pathways $93 ; 255$ and we have obtained evidence that tau potentiates NGF-induced MAPK activation ${ }^{213}$. However, despite available co-immunoprecipitation data for some interactions, the specific molecular complexes that engage tau as a signal transduction protein remain to be identified. Also, the functional significance of both the tyrosine phosphorylation of tau and its increased phosphorylation during development remain unclear.

While the microtubule associated functions of tau are important, its function in signaling may be equally important and it is unclear which functions are most critical during the neurodegenerative process. Establishing new functions for tau would lead to new hypotheses regarding the connection between tau and neurodegenerative disease. If a non-filamentous form of hyperphosphorylated tau is responsible for early behavioral deficits, understanding the role of phosphorylated tau during development and in signal transduction may provide clues to pathways that are mis-regulated during the disease process.

\section{References}

1. Weingarten MD, Lockwood AH, Hwo SY, Kirschner MW. A protein factor essential for microtubule assembly. Proc Natl Acad Sci U S A. 1975; 72:1858-62. [PubMed: 1057175]

2. Lee G, Cowan N, Kirschner M. The primary structure and heterogeneity of tau protein from mouse brain. Science. 1988; 239:285-8. [PubMed: 3122323]

3. Caceres A, Potrebic S, Kosik KS. The effect of tau antisence oligonucleotides on neurite formation of cultured cerebellar macroneurons. J Neurosci. 1991; 11:1515-23. [PubMed: 1904479]

4. Harada A, Oguchi K, Okabe S, Kuno J, Terada S, Ohshima T, Sato-Yoshitake R, Takei Y, Noda T, Hirokawa N. Altered microtubule organization in small-calibre axons of mice lacking tau protein. Nature. 1994; 369:488-91. [PubMed: 8202139] 
5. Dawson HN, Ferreira A, Eyster MV, Ghoshal N, Binder LI, Vitek MP. Inhibition of neuronal maturation in primary hippocampal neurons from tau deficient mice. J Cell Sci. 2001; 114:1179-87. [PubMed: 11228161]

6. Takei Y, Teng J, Harada A, Hirokawa N. Defects in axonal elongation and neuronal migration in mice with disrupted tau and map1b genes. Journal of Cell Biology. 2000; 150:989-1000. [PubMed: 10973990]

7. Lewis SA, Wang DH, Cowan NJ. Microtubule-associated protein MAP2 shares a microtubule binding motif with tau protein. Science. 1988; 242:936-9. [PubMed: 3142041]

8. Chapin SJ, Bulinski JC. Non-neuronal $210 \times 10(3)$ Mr microtubule-associated protein (MAP4) contains a domain homologous to the microtubule-binding domains of neuronal MAP2 and tau. J Cell Sci. 1991; 98:27-36. [PubMed: 1905296]

9. Wood JG, Mirra SS, Pollock NJ, Binder LI. Neurofibrillary tangles of Alzheimer disease share antigenic determinants with the axonal microtubule-associated protein tau (tau) [published erratum appears in Proc Natl Acad Sci U S A 1986 Dec;83(24):9773]. Proc Natl Acad Sci U S A. 1986; 83:4040-3. [PubMed: 2424015]

10. Grundke II, Iqbal K, Tung YC, Quinlan M, Wisniewski HM, Binder LI. Abnormal phosphorylation of the microtubule-associated protein tau (tau) in Alzheimer cytoskeletal pathology. Proc Natl Acad Sci U S A. 1986; 83:4913-7. [PubMed: 3088567]

11. Kosik KS, Joachim CL, Selkoe DJ. Microtubule-associated protein tau (tau) is a major antigenic component of paired helical filaments in Alzheimer disease. Proceedings of the National Academy of Sciences of the United States of America. 1986; 83:4044-8. [PubMed: 2424016]

12. Hutton M, Lendon CL, Rizzu P, Baker M, Froelich S, Houlden H, Pickeringbrown S, Chakraverty S, Isaacs A, Grover A, Hackett J, Adamson J, Lincoln S, Dickson D, Davies P, Petersen RC, Stevens M, Degraaff E, Wauters E, Vanbaren J, Hillebrand M, Joosse M, Kwon JM, Nowotny P, Che LK, et al. Association of missense and $5^{\prime}$-splice-site mutations in tau with the inherited dementia FTDP-17. Nature. 1998; 393:702-705. [PubMed: 9641683]

13. Spillantini MG, Murrell JR, Goedert M, Farlow MR, Klug A, Ghetti B. Mutation in the tau gene in familial multiple system tauopathy with presenile dementia. Proc Natl Acad Sci USA. 1998; 95:7737-7741. [PubMed: 9636220]

14. Poorkaj P, Bird TD, Wijsman E, Nemens E, Garruto RM, Anderson L, Andreadis A, Wiederholt WC, Raskind M, Schellenberg GD. Tau is a candidate gene for chromosome 17 frontotemporal dementia. Ann of Neurol. 1998; 43:815-825. [PubMed: 9629852]

15. Lee VM, Kenyon TK, Trojanowski JQ. Transgenic animal models of tauopathies. Biochim Biophys Acta. 2005; 1739:251-9. [PubMed: 15615643]

16. Gotz J, Ittner LM. Animal models of Alzheimer's disease and frontotemporal dementia. Nat Rev Neurosci. 2008; 9:532-44. [PubMed: 18568014]

17. Denk F, Wade-Martins R. Knock-out and transgenic mouse models of tauopathies. Neurobiol Aging. 2009; 30:1-13. [PubMed: 17590238]

18. Frank S, Clavaguera F, Tolnay M. Tauopathy models and human neuropathology: similarities and differences. Acta Neuropathol. 2008; 115:39-53. [PubMed: 17786456]

19. Neve RL, Harris P, Kosik KS, Kurnit DM, Donlon TA. Identification of cDNA clones for the human microtubule-associated protein tau and chromosomal localization of the genes for tau and microtubule-associated protein 2. Brain Res. 1986; 387:271-80. [PubMed: 3103857]

20. Andreadis A, Brown WM, Kosik KS. Structure and novel exons of the human tau gene. Biochem. 1992; 31:10626-33. [PubMed: 1420178]

21. Baker M, Litvan I, Houlden H, Adamson J, Dickson D, Perez-Tur J, Hardy J, Lynch T, Bigio E, Hutton M. Association of an extended haplotype in the tau gene with progressive supranuclear palsy. Hum Mol Genet. 1999; 8:711-5. [PubMed: 10072441]

22. Goedert M, Spillantini MG, Jakes R, Rutherford D, Crowther RA. Multiple isoforms of human microtubule-associated protein tau: sequences and localization in neurofibrillary tangles of Alzheimer's disease. Neuron. 1989; 3:519-26. [PubMed: 2484340]

23. Goedert M, Jakes R. Expression of separate isoforms of human tau protein: correlation with the tau pattern in brain and effects on tubulin polymerization. Embo J. 1990; 9:4225-30. [PubMed: 2124967] 
24. Hong M, Zhukareva V, Vogelsberg-Ragaglia V, Wszolek Z, Reed L, Miller BI, Geschwind DH, Bird TD, McKeel D, Goate A, Morris JC, Wilhelmsen KC, Schellenberg GD, Trojanowski JQ, Lee VM. Mutation-specific functional impairments in distinct tau isoforms of hereditary FTDP-17. Science. 1998; 282:1914-7. [PubMed: 9836646]

25. Kosik KS, Orecchio LD, Bakalis S, Neve RL. Developmentally regulated expression of specific tau sequences. Neuron. 1989; 2:1389-97. [PubMed: 2560640]

26. Himmler A, Drechsel D, Kirschner MW, Martin DJ. Tau consists of a set of proteins with repeated C-terminal microtubule-binding domains and variable N-terminal domains. Mol Cell Biol. 1989; 9:1381-8. [PubMed: 2498649]

27. Nelson PT, Stefansson K, Gulcher J, Saper CB. Molecular evolution of tau protein: implications for Alzheimer's disease. Journal of Neurochemistry. 1996; 67:1622-32. [PubMed: 8858947]

28. Yoshida H, Goedert M. Molecular cloning and functional characterization of chicken brain tau: isoforms with up to five tandem repeats. Biochemistry. 2002; 41:15203-11. [PubMed: 12484758]

29. Goedert M, Baur CP, Ahringer J, Jakes R, Hasegawa M, Spillantini MG, Smith MJ, Hill F. PTL-1, a microtubule-associated protein with tau-like repeats from the nematode Caenorhabditis elegans. J Cell Sci. 1996; 109 (Pt 11):2661-72. [PubMed: 8937984]

30. Chen M, Martins RN, Lardelli M. Complex splicing and neural expression of duplicated tau genes in zebrafish embryos. J Alzheimers Dis. 2009; 18:305-17. [PubMed: 19584432]

31. Olesen OF, Kawabata-Fukui H, Yoshizato K, Noro N. Molecular cloning of XTP, a tau-like microtubule-associated protein from Xenopus laevis tadpoles. Gene. 2002; 283:299-309. [PubMed: 11867237]

32. Goode BL, Feinstein SC. Identification of a novel microtubule binding and assembly domain in the developmentally regulated inter-repeat region of tau. J Cell Biol. 1994; 124:769-82. [PubMed: 8120098]

33. Trinczek B, Biernat J, Baumann K, Mandelkow EM, Mandelkow E. Domains of tau protein, differential phosphorylation, and dynamic instability of microtubules. Mol Biol Cell. 1995; 6:1887-902. [PubMed: 8590813]

34. Mukrasch MD, von Bergen M, Biernat J, Fischer D, Griesinger C, Mandelkow E, Zweckstetter M. The "jaws" of the tau-microtubule interaction. J Biol Chem. 2007; 282:12230-9. [PubMed: 17307736]

35. Lindwall G, Cole RD. Phosphorylation affects the ability of tau protein to promote microtubule assembly. J Biol Chem. 1984; 259:5301-5. [PubMed: 6425287]

36. Watanabe A, Hasegawa M, Suzuki M, Takio K, Morishima-Kawashima M, Titani K, Arai T, Kosik KS, Ihara Y. In vivo phosphorylation sites in fetal and adult rat tau. J Biol Chem. 1993; 268:25712-7. [PubMed: 8245007]

37. Oyama F, Kotliarova S, Harada A, Ito M, Miyazaki H, Ueyama Y, Hirokawa N, Nukina N, Ihara Y. Gem GTPase and tau: morphological changes induced by gem GTPase in cho cells are antagonized by tau. J Biol Chem. 2004; 279:27272-7. [PubMed: 15087445]

38. Ikegami S, Harada A, Hirokawa N. Muscle weakness, hyperactivity, and impairment in fear conditioning in tau-deficient mice. Neuroscience Letters. 2000; 279:129-32. [PubMed: 10688046]

39. Roberson ED, Scearce-Levie K, Palop JJ, Yan F, Cheng IH, Wu T, Gerstein H, Yu GQ, Mucke L. Reducing endogenous tau ameliorates amyloid beta-induced deficits in an Alzheimer's disease mouse model. Science. 2007; 316:750-4. [PubMed: 17478722]

40. Gu Y, Oyama F, Ihara Y. $\tau$ is widely expressed in rat tissues. J Neurochem. 1996; 76:1235-44. [PubMed: 8752131]

41. Kenner L, el-Shabrawi Y, Hutter H, Forstner M, Zatloukal K, Hoefler G, Preisegger KH, Kurzbauer R, Denk H. Expression of three- and four-repeat tau isoforms in mouse liver. Hepatology. 1994; 20:1086-9. [PubMed: 7927211]

42. Sangrajrang S, Denoulet P, Millot G, Tatoud R, Podgorniak MP, Tew KD, Calvo F, Fellous A. Estramustine resistance correlates with tau over-expression in human prostatic carcinoma cells. Int J Cancer. 1998; 77:626-31. [PubMed: 9679768]

43. Souter S, Lee G. Microtubule-associated protein tau in human prostate cancer cells: Isoforms, phosphorylation, and interactions. J Cell Biochem. 2009; 108:555-64. [PubMed: 19681044] 
44. Rouzier R, Rajan R, Wagner P, Hess KR, Gold DL, Stec J, Ayers M, Ross JS, Zhang P, Buchholz TA, Kuerer H, Green M, Arun B, Hortobagyi GN, Symmans WF, Pusztai L. Microtubuleassociated protein tau: a marker of paclitaxel sensitivity in breast cancer. Proc Natl Acad Sci U S A. 2005; 102:8315-20. [PubMed: 15914550]

45. Mimori K, Sadanaga N, Yoshikawa Y, Ishikawa K, Hashimoto M, Tanaka F, Sasaki A, Inoue H, Sugimachi K, Mori M. Reduced tau expression in gastric cancer can identify candidates for successful Paclitaxel treatment. Br J Cancer. 2006; 94:1894-7. [PubMed: 16721363]

46. Jimeno A, Hallur G, Chan A, Zhang X, Cusatis G, Chan F, Shah P, Chen R, Hamel E, GarrettMayer E, Khan S, Hidalgo M. Development of two novel benzoylphenylurea sulfur analogues and evidence that the microtubule-associated protein tau is predictive of their activity in pancreatic cancer. Mol Cancer Ther. 2007; 6:1509-16. [PubMed: 17483439]

47. Askanas V, Engel WK, Bilak M, Alvarez RB, Selkoe DJ. Twisted tubulofilaments of inclusion body myositis muscle resemble paired helical filaments of Alzheimer brain and contain hyperphosphorylated tau. Am J Pathol. 1994; 144:177-87. [PubMed: 8291607]

48. Ballatore C, Lee VM, Trojanowski JQ. Tau-mediated neurodegeneration in Alzheimer's disease and related disorders. Nat Rev Neurosci. 2007; 8:663-72. [PubMed: 17684513]

49. Chun W, Johnson GV. The role of tau phosphorylation and cleavage in neuronal cell death. Front Biosci. 2007; 12:733-56. [PubMed: 17127334]

50. Hardy J, Selkoe DJ. The amyloid hypothesis of Alzheimer's disease: progress and problems on the road to therapeutics. Science. 2002; 297:353-6. [PubMed: 12130773]

51. Rapoport M, Dawson HN, Binder LI, Vitek MP, Ferreira A. Tau is essential to beta -amyloidinduced neurotoxicity. Proc Natl Acad Sci U S A. 2002; 99:6364-9. [PubMed: 11959919]

52. Goedert M. Tau protein and neurodegeneration. Semin Cell Dev Biol. 2004; 15:45-9. [PubMed: 15036206]

53. Yancopoulou D, Spillantini MG. Tau protein in familial and sporadic diseases. Neuromolecular Med. 2003; 4:37-48. [PubMed: 14528051]

54. Dickson DW. Neuropathology of non-Alzheimer degenerative disorders. Int J Clin Exp Pathol. 2009; 3:1-23. [PubMed: 19918325]

55. Ludolph AC, Kassubek J, Landwehrmeyer BG, Mandelkow E, Mandelkow EM, Burn DJ, Caparros-Lefebvre D, Frey KA, de Yebenes JG, Gasser T, Heutink P, Hoglinger G, Jamrozik Z, Jellinger KA, Kazantsev A, Kretzschmar H, Lang AE, Litvan I, Lucas JJ, McGeer PL, Melquist S, Oertel W, Otto M, Paviour D, Reum T, Saint-Raymond A, Steele JC, Tolnay M, Tumani H, van Swieten JC, Vanier MT, Vonsattel JP, Wagner S, Wszolek ZK. Tauopathies with parkinsonism: clinical spectrum, neuropathologic basis, biological markers, and treatment options. Eur J Neurol. 2009; 16:297-309. [PubMed: 19364361]

56. Wolfe MS. Tau mutations in neurodegenerative diseases. J Biol Chem. 2009; 284:6021-5. [PubMed: 18948254]

57. van Swieten J, Spillantini MG. Hereditary frontotemporal dementia caused by Tau gene mutations. Brain Pathol. 2007; 17:63-73. [PubMed: 17493040]

58. Lee VM, Goedert M, Trojanowski JQ. Neurodegenerative tauopathies. Annu Rev Neurosci. 2001; 24:1121-59. [PubMed: 11520930]

59. Grover A, Houlden H, Baker M, Adamson J, Lewis J, Prihar G, Pickering-Brown S, Duff K, Hutton M. 5' splice site mutations in tau associated with the inherited dementia FTDP-17 affect a stem-loop structure that regulates alternative splicing of exon 10. J Biol Chem. 1999; 274:1513443. [PubMed: 10329720]

60. Myers AJ, Pittman AM, Zhao AS, Rohrer K, Kaleem M, Marlowe L, Lees A, Leung D, McKeith IG, Perry RH, Morris CM, Trojanowski JQ, Clark C, Karlawish J, Arnold S, Forman MS, Van Deerlin V, de Silva R, Hardy J. The MAPT H1c risk haplotype is associated with increased expression of tau and especially of 4 repeat containing transcripts. Neurobiol Dis. 2007; 25:56170. [PubMed: 17174556]

61. Gotz J, Deters N, Doldissen A, Bokhari L, Ke Y, Wiesner A, Schonrock N, Ittner LM. A decade of tau transgenic animal models and beyond. Brain Pathol. 2007; 17:91-103. [PubMed: 17493043]

62. McGowan E, Eriksen J, Hutton M. A decade of modeling Alzheimer's disease in transgenic mice. Trends Genet. 2006; 22:281-9. [PubMed: 16567017] 
63. Oddo S, Caccamo A, Shepherd JD, Murphy MP, Golde TE, Kayed R, Metherate R, Mattson MP, Akbari Y, LaFerla FM. Triple-transgenic model of Alzheimer's disease with plaques and tangles: intracellular Abeta and synaptic dysfunction. Neuron. 2003; 39:409-21. [PubMed: 12895417]

64. Ferrari A, Hoerndli F, Baechi T, Nitsch RM, Gotz J. beta-Amyloid induces paired helical filamentlike tau filaments in tissue culture. Journal of Biological Chemistry. 2003; 278:40162-8. [PubMed: 12893817]

65. DeTure M, Ko LW, Easson C, Yen SH. Tau assembly in inducible transfectants expressing wildtype or FTDP-17 tau. Am J Pathol. 2002; 161:1711-22. [PubMed: 12414518]

66. von Bergen M, Barghorn S, Biernat J, Mandelkow EM, Mandelkow E. Tau aggregation is driven by a transition from random coil to beta sheet structure. Biochim Biophys Acta. 2005; 1739:15866. [PubMed: 15615635]

67. Binder LI, Guillozet-Bongaarts AL, Garcia-Sierra F, Berry RW. Tau, tangles, and Alzheimer's disease. Biochim Biophys Acta. 2005; 1739:216-23. [PubMed: 15615640]

68. Gamblin TC, Berry RW, Binder LI. Modeling tau polymerization in vitro: a review and synthesis. Biochemistry. 2003; 42:15009-17. [PubMed: 14690409]

69. von Bergen M, Friedhoff P, Biernat J, Heberle J, Mandelkow EM, Mandelkow E. Assembly of $\tau$ protein into Alzheimer paired helical filaments depends on a local sequence motif $\left({ }^{306}\right.$ VQIVYK $\left.{ }^{311}\right)$ forming $\beta$ structure. Proc Natl Acad Sci USA. 2000; 97:5129-34. [PubMed: 10805776]

70. Gamblin TC, Chen F, Zambrano A, Abraha A, Lagalwar S, Guillozet AL, Lu M, Fu Y, GarciaSierra F, LaPointe N, Miller R, Berry RW, Binder LI, Cryns VL. Caspase cleavage of tau: linking amyloid and neurofibrillary tangles in Alzheimer's disease. Proc Natl Acad Sci U S A. 2003; 100:10032-7. [PubMed: 12888622]

71. Gamblin TC, King ME, Dawson H, Vitek MP, Kuret J, Berry RW, Binder LI. In vitro polymerization of tau protein monitored by laser light scattering: method and application to the study of FTDP-17 mutants. Biochemistry. 2000; 39:6136-44. [PubMed: 10821687]

72. von Bergen M, Barghorn S, Li L, Marx A, Biernat J, Mandelkow EM, Mandelkow E. Mutations of tau protein in frontotemporal dementia promote aggregation of paired helical filaments by enhancing local beta-structure. Journal of Biological Chemistry. 2001; 276:48165-74. [PubMed: 11606569]

73. Eidenmuller J, Fath T, Maas T, Pool M, Sontag E, Brandt R. Phosphorylation-mimicking glutamate clusters in the proline-rich region are sufficient to simulate the functional deficiencies of hyperphosphorylated tau protein. Biochem J. 2001; 357:759-67. [PubMed: 11463346]

74. Schneider A, Biernat J, von Bergen M, Mandelkow E, Mandelkow EM. Phosphorylation that detaches tau protein from microtubules (Ser262, Ser214) also protects it against aggregation into Alzheimer paired helical filaments. Biochemistry. 1999; 38:3549-58. [PubMed: 10090741]

75. Sun Q, Gamblin TC. Pseudohyperphosphorylation causing AD-like changes in tau has significant effects on its polymerization. Biochemistry. 2009; 48:6002-11. [PubMed: 19459590]

76. Necula M, Kuret J. Pseudophosphorylation and glycation of tau protein enhance but do not trigger fibrillization in vitro. J Biol Chem. 2004; 279:49694-703. [PubMed: 15364924]

77. SantaCruz K, Lewis J, Spires T, Paulson J, Kotilinek L, Ingelsson M, Guimaraes A, DeTure M, Ramsden M, McGowan E, Forster C, Yue M, Orne J, Janus C, Mariash A, Kuskowski M, Hyman $\mathrm{B}$, Hutton M, Ashe KH. Tau suppression in a neurodegenerative mouse model improves memory function. Science. 2005; 309:476-81. [PubMed: 16020737]

78. Kimura T, Yamashita S, Fukuda T, Park JM, Murayama M, Mizoroki T, Yoshiike Y, Sahara N, Takashima A. Hyperphosphorylated tau in parahippocampal cortex impairs place learning in aged mice expressing wild-type human tau. Embo J. 2007; 26:5143-52. [PubMed: 18007595]

79. Taniguchi T, Doe N, Matsuyama S, Kitamura Y, Mori H, Saito N, Tanaka C. Transgenic mice expressing mutant (N279K) human tau show mutation dependent cognitive deficits without neurofibrillary tangle formation. FEBS Lett. 2005; 579:5704-12. [PubMed: 16219306]

80. Wittmann CW, Wszolek MF, Shulman JM, Salvaterra PM, Lewis J, Hutton M, Feany MB. Tauopathy in Drosophila: neurodegeneration without neurofibrillary tangles. Science. 2001; 293:711-4. [PubMed: 11408621] 
81. Kraemer BC, Zhang B, Leverenz JB, Thomas JH, Trojanowski JQ, Schellenberg GD. Neurodegeneration and defective neurotransmission in a Caenorhabditis elegans model of tauopathy. Proceedings of the National Academy of Sciences of the United States of America. 2003; 100:9980-5. [PubMed: 12872001]

82. Sahara N, Maeda S, Takashima A. Tau oligomerization: a role for tau aggregation intermediates linked to neurodegeneration. Curr Alzheimer Res. 2008; 5:591-8. [PubMed: 19075586]

83. Iqbal K, Liu F, Gong CX, Alonso Adel C, Grundke-Iqbal I. Mechanisms of tau-induced neurodegeneration. Acta Neuropathol. 2009; 118:53-69. [PubMed: 19184068]

84. Bretteville A, Planel E. Tau aggregates: toxic, inert, or protective species? J Alzheimers Dis. 2008; 14:431-6. [PubMed: 18688094]

85. Lee HG, Perry G, Moreira PI, Garrett MR, Liu Q, Zhu X, Takeda A, Nunomura A, Smith MA. Tau phosphorylation in Alzheimer's disease: pathogen or protector? Trends Mol Med. 2005; 11:164-9. [PubMed: 15823754]

86. Bramblett GT, Goedert M, Jakes R, Merrick SE, Trojanowski JQ, Lee VMY. Abnormal tau phosphorylation at $\mathrm{Ser}^{396}$ in Alzheimer's disease recapitulates development and contributes to reduced microtubule binding. Neuron. 1993; 10:1089-99. [PubMed: 8318230]

87. Kanemaru K, Takio K, Miura R, Titani K, Ihara Y. Fetal-type phosphorylation of the tau in paired helical filaments. J Neurochem. 1992; 58:1667-75. [PubMed: 1560225]

88. Brion JP, Smith C, Couck AM, Gallo JM, Anderton BH. Developmental changes in tau phosphorylation: fetal tau is transiently phosphorylated in a manner similar to paired helical filament-tau characteristic of Alzheimer's disease. J Neurochem. 1993; 61:2071-80. [PubMed: 8245963]

89. Brunden KR, Trojanowski JQ, Lee VM. Advances in tau-focused drug discovery for Alzheimer's disease and related tauopathies. Nat Rev Drug Discov. 2009; 8:783-93. [PubMed: 19794442]

90. Gong CX, Iqbal K. Hyperphosphorylation of microtubule-associated protein tau: a promising therapeutic target for Alzheimer disease. Curr Med Chem. 2008; 15:2321-8. [PubMed: 18855662]

91. Gotz J, Gladbach A, Pennanen L, van Eersel J, Schild A, David D, Ittner LM. Animal models reveal role for tau phosphorylation in human disease. Biochim Biophys Acta. 2010; 1802:860-71. [PubMed: 19751831]

92. Noble W, Planel E, Zehr C, Olm V, Meyerson J, Suleman F, Gaynor K, Wang L, LaFrancois J, Feinstein B, Burns M, Krishnamurthy P, Wen Y, Bhat R, Lewis J, Dickson D, Duff K. Inhibition of glycogen synthase kinase-3 by lithium correlates with reduced tauopathy and degeneration in vivo. Proc Natl Acad Sci U S A. 2005; 102:6990-5. [PubMed: 15867159]

93. Khurana V, Lu Y, Steinhilb ML, Oldham S, Shulman JM, Feany MB. TOR-mediated cell-cycle activation causes neurodegeneration in a Drosophila tauopathy model. Curr Biol. 2006; 16:230 41. [PubMed: 16461276]

94. Yang Y, Herrup K. Cell division in the CNS: protective response or lethal event in post-mitotic neurons? Biochim Biophys Acta. 2007; 1772:457-66. [PubMed: 17158035]

95. Lee HG, Casadesus G, Zhu X, Castellani RJ, McShea A, Perry G, Petersen RB, Bajic V, Smith MA. Cell cycle re-entry mediated neurodegeneration and its treatment role in the pathogenesis of Alzheimer's disease. Neurochem Int. 2009; 54:84-8. [PubMed: 19114068]

96. Vincent I, Rosado M, Davies P. Mitotic mechanisms in Alzheimer's disease? Journal of Cell Biology. 1996; 132:413-25. [PubMed: 8636218]

97. Preuss U, Mandelkow EM. Mitotic phosphorylation of tau protein in neuronal cell lines resembles phosphorylation in Alzheimer's disease. Eur J Cell Biol. 1998; 76:176-84. [PubMed: 9716264]

98. Illenberger S, Zheng-Fischhofer Q, Preuss U, Stamer K, Baumann K, Trinczek B, Biernat J, Godemann R, Mandelkow EM, Mandelkow E. The endogenous and cell cycle-dependent phosphorylation of tau protein in living cells: implications for Alzheimer's disease. Mol Biol Cell. 1998; 9:1495-512. [PubMed: 9614189]

99. Delobel P, Flament S, Hamdane M, Mailliot C, Sambo AV, Begard S, Sergeant N, Delacourte A, Vilain JP, Buee L. Abnormal Tau phosphorylation of the Alzheimer-type also occurs during mitosis. J Neurochem. 2002; 83:412-20. [PubMed: 12423251]

100. Yang Y, Geldmacher DS, Herrup K. DNA replication precedes neuronal cell death in Alzheimer's disease. J Neurosci. 2001; 21:2661-8. [PubMed: 11306619] 
101. Drechsel DN, Hyman AA, Cobb MH, Kirschner MW. Modulation of the dynamic instability of tubulin assembly by the microtubule-associated protein tau. Mol Biol Cell. 1992; 3:1141-54. [PubMed: 1421571]

102. Lee G, Rook SL. Expression of tau protein in non-neuronal cells: microtubule binding and stabilization. J Cell Sci. 1992; 102 (Pt 2):227-37. [PubMed: 1400630]

103. Brandt R, Lee G. Functional organization of microtubule-associated protein tau. Identification of regions which affect microtubule growth, nucleation, and bundle formation in vitro. J Biol Chem. 1993; 268:3414-9. [PubMed: 8429017]

104. Gustke N, Trinczek B, Biernat J, Mandelkow EM, Mandelkow E. Domains of tau protein and interactions with microtubules. Biochemistry. 1994; 33:9511-22. [PubMed: 8068626]

105. Goode BL, Denis PE, Panda D, Radeke MJ, Miller HP, Wilson L, Feinstein SC. Functional interactions between the proline-rich and repeat regions of tau enhance microtubule binding and assembly. Mol Biol Cell. 1997; 8:353-65. [PubMed: 9190213]

106. Mukrasch MD, Biernat J, von Bergen M, Griesinger C, Mandelkow E, Zweckstetter M. Sites of tau important for aggregation populate $\{$ beta $\}$-structure and bind to microtubules and polyanions. J Biol Chem. 2005; 280:24978-86. [PubMed: 15855160]

107. Sillen A, Barbier P, Landrieu I, Lefebvre S, Wieruszeski JM, Leroy A, Peyrot V, Lippens G. NMR investigation of the interaction between the neuronal protein tau and the microtubules. Biochemistry. 2007; 46:3055-64. [PubMed: 17311412]

108. Jeganathan S, von Bergen M, Brutlach H, Steinhoff HJ, Mandelkow E. Global hairpin folding of tau in solution. Biochemistry. 2006; 45:2283-93. [PubMed: 16475817]

109. Panda D, Samuel JC, Massie M, Feinstein SC, Wilson L. Differential regulation of microtubule dynamics by three- and four-repeat tau: implications for the onset of neurodegenerative disease. Proceedings of the National Academy of Sciences of the United States of America. 2003; 100:9548-53. [PubMed: 12886013]

110. Levy SF, Leboeuf AC, Massie MR, Jordan MA, Wilson L, Feinstein SC. Three- and four-repeat tau regulate the dynamic instability of two distinct microtubule subpopulations in qualitatively different manners. Implications for neurodegeneration. J Biol Chem. 2005; 280:13520-8. [PubMed: 15671021]

111. Al-Bassam J, Ozer RS, Safer D, Halpain S, Milligan RA. MAP2 and tau bind longitudinally along the outer ridges of microtubule protofilaments. J Cell Biol. 2002; 157:1187-96. [PubMed: 12082079]

112. Choi MC, Raviv U, Miller HP, Gaylord MR, Kiris E, Ventimiglia D, Needleman DJ, Kim MW, Wilson L, Feinstein SC, Safinya CR. Human microtubule-associated-protein tau regulates the number of protofilaments in microtubules: a synchrotron x-ray scattering study. Biophys J. 2009; 97:519-27. [PubMed: 19619466]

113. Dayanandan R, Van Slegtenhorst M, Mack TG, Ko L, Yen SH, Leroy K, Brion JP, Anderton BH, Hutton M, Lovestone S. Mutations in tau reduce its microtubule binding properties in intact cells and affect its phosphorylation. FEBS Lett. 1999; 446:228-32. [PubMed: 10100846]

114. Hasegawa M, Smith MJ, Goedert M. Tau proteins with FTDP-17 mutations have a reduced ability to promote microtubule assembly. FEBS Letters. 1998; 437:207-10. [PubMed: 9824291]

115. Barghorn S, Zheng-Fischhofer Q, Ackmann M, Biernat J, von Bergen M, Mandelkow EM, Mandelkow E. Structure, microtubule interactions, and paired helical filament aggregation by tau mutants of frontotemporal dementias. Biochemistry. 2000; 39:11714-21. [PubMed: 10995239]

116. Fischer D, Mukrasch MD, von Bergen M, Klos-Witkowska A, Biernat J, Griesinger C, Mandelkow E, Zweckstetter M. Structural and microtubule binding properties of tau mutants of frontotemporal dementias. Biochemistry. 2007; 46:2574-82. [PubMed: 17297915]

117. Bunker JM, Kamath K, Wilson L, Jordan MA, Feinstein SC. FTDP-17 mutations compromise the ability of tau to regulate microtubule dynamics in cells. J Biol Chem. 2006; 281:11856-63. [PubMed: 16495230]

118. Delobel P, Flament S, Hamdane M, Jakes R, Rousseau A, Delacourte A, Vilain JP, Goedert M, Buee L. Functional characterization of FTDP-17 tau gene mutations through their effects on Xenopus oocyte maturation. J Biol Chem. 2002; 277:9199-205. [PubMed: 11756436] 
119. Biernat J, Gustke N, Drewes G, Mandelkow EM, Mandelkow E. Phosphorylation of Ser262 strongly reduces binding of tau to microtubules: distinction between PHF-like immunoreactivity and microtubule binding. Neuron. 1993; 11:153-63. [PubMed: 8393323]

120. Leger J, Kempf M, Lee G, Brandt R. Conversion of serine to aspartate imitates phosphorylationinduced changes in the structure and function of microtubule-associated protein tau. J Biol Chem. 1997; 272:8441-6. [PubMed: 9079670]

121. Haase C, Stieler JT, Arendt T, Holzer M. Pseudophosphorylation of tau protein alters its ability for self-aggregation. J Neurochem. 2004; 88:1509-20. [PubMed: 15009652]

122. Cho JH, Johnson GV. Primed phosphorylation of tau at Thr231 by glycogen synthase kinase 3beta (GSK3beta) plays a critical role in regulating tau's ability to bind and stabilize microtubules. J Neurochem. 2004; 88:349-58. [PubMed: 14690523]

123. Feinstein SC, Wilson L. Inability of tau to properly regulate neuronal microtubule dynamics: a loss-of-function mechanism by which tau might mediate neuronal cell death. Biochim Biophys Acta. 2005; 1739:268-79. [PubMed: 15615645]

124. Brunden KR, Zhang B, Carroll J, Yao Y, Potuzak JS, Hogan AM, Iba M, James MJ, Xie SX, Ballatore C, Smith AB 3rd, Lee VM, Trojanowski JQ. Epothilone D improves microtubule density, axonal integrity, and cognition in a transgenic mouse model of tauopathy. J Neurosci. 2010; 30:13861-6. [PubMed: 20943926]

125. Morfini GA, Burns M, Binder LI, Kanaan NM, LaPointe N, Bosco DA, Brown RH Jr, Brown H, Tiwari A, Hayward L, Edgar J, Nave KA, Garbern J, Atagi Y, Song Y, Pigino G, Brady ST. Axonal transport defects in neurodegenerative diseases. J Neurosci. 2009; 29:12776-86. [PubMed: 19828789]

126. Ebneth A, Godemann R, Stamer K, Illenberger S, Trinczek B, Mandelkow E. Overexpression of tau protein inhibits kinesin-dependent trafficking of vesicles, mitochondria, and endoplasmic reticulum: implications for Alzheimer's disease. J Cell Biol. 1998; 143:777-94. [PubMed: 9813097]

127. Trinczek B, Ebneth A, Mandelkow EM, Mandelkow E. Tau regulates the attachment/detachment but not the speed of motors in microtubule-dependent transport of single vesicles and organelles. J Cell Sci. 1999; 112 (Pt 14):2355-67. [PubMed: 10381391]

128. Hall GF, Lee VM, Lee G, Yao J. Staging of neurofibrillary degeneration caused by human tau overexpression in a unique cellular model of human tauopathy. Am J Pathol. 2001; 158:235-46. [PubMed: 11141497]

129. Stamer K, Vogel R, Thies E, Mandelkow E, Mandelkow EM. Tau blocks traffic of organelles, neurofilaments, and APP vesicles in neurons and enhances oxidative stress. J Cell Biol. 2002; 156:1051-63. [PubMed: 11901170]

130. Mandelkow EM, Stamer K, Vogel R, Thies E, Mandelkow E. Clogging of axons by tau, inhibition of axonal traffic and starvation of synapses. Neurobiol Aging. 2003; 24:1079-85. [PubMed: 14643379]

131. Ishihara T, Hong M, Zhang B, Nakagawa Y, Lee MK, Trojanowski JQ, Lee VM. Age-dependent emergence and progression of a tauopathy in transgenic mice overexpressing the shortest human tau isoform. Neuron. 1999; 24:751-62. [PubMed: 10595524]

132. Ittner LM, Fath T, Ke YD, Bi M, van Eersel J, Li KM, Gunning P, Gotz J. Parkinsonism and impaired axonal transport in a mouse model of frontotemporal dementia. Proc Natl Acad Sci U S A. 2008; 105:15997-6002. [PubMed: 18832465]

133. Utton MA, Noble WJ, Hill JE, Anderton BH, Hanger DP. Molecular motors implicated in the axonal transport of tau and alpha-synuclein. J Cell Sci. 2005; 118:4645-54. [PubMed: 16176937]

134. Dubey M, Chaudhury P, Kabiru H, Shea TB. Tau inhibits anterograde axonal transport and perturbs stability in growing axonal neurites in part by displacing kinesin cargo: neurofilaments attenuate tau-mediated neurite instability. Cell Motil Cytoskeleton. 2008; 65:89-99. [PubMed: 18000878]

135. Jancsik V, Filliol D, Rendon A. Tau proteins bind to kinesin and modulate its activation by microtubules. Neurobiology (Bp). 1996; 4:417-29. [PubMed: 9200133] 
136. Cuchillo-Ibanez I, Seereeram A, Byers HL, Leung KY, Ward MA, Anderton BH, Hanger DP. Phosphorylation of tau regulates its axonal transport by controlling its binding to kinesin. Faseb J. 2008; 22:3186-95. [PubMed: 18511549]

137. Magnani E, Fan J, Gasparini L, Golding M, Williams M, Schiavo G, Goedert M, Amos LA, Spillantini MG. Interaction of tau protein with the dynactin complex. Embo J. 2007; 26:4546-54. [PubMed: 17932487]

138. Seitz A, Kojima H, Oiwa K, Mandelkow EM, Song YH, Mandelkow E. Single-molecule investigation of the interference between kinesin, tau and MAP2c. Embo J. 2002; 21:4896-905. [PubMed: 12234929]

139. Dixit R, Ross JL, Goldman YE, Holzbaur EL. Differential regulation of dynein and kinesin motor proteins by tau. Science. 2008; 319:1086-9. [PubMed: 18202255]

140. Vershinin M, Carter BC, Razafsky DS, King SJ, Gross SP. Multiple-motor based transport and its regulation by Tau. Proc Natl Acad Sci U S A. 2007; 104:87-92. [PubMed: 17190808]

141. Ittner LM, Ke YD, Gotz J. Phosphorylated Tau interacts with c-Jun N-terminal kinase-interacting protein 1 (JIP1) in Alzheimer disease. J Biol Chem. 2009; 284:20909-16. [PubMed: 19491104]

142. Shemesh OA, Erez H, Ginzburg I, Spira ME. Tau-induced traffic jams reflect organelles accumulation at points of microtubule polar mismatching. Traffic. 2008; 9:458-71. [PubMed: 18182010]

143. Morfini G, Pigino G, Mizuno N, Kikkawa M, Brady ST. Tau binding to microtubules does not directly affect microtubule-based vesicle motility. J Neurosci Res. 2007; 85:2620-30. [PubMed: 17265463]

144. LaPointe NE, Morfini G, Pigino G, Gaisina IN, Kozikowski AP, Binder LI, Brady ST. The amino terminus of tau inhibits kinesin-dependent axonal transport: implications for filament toxicity. J Neurosci Res. 2009; 87:440-51. [PubMed: 18798283]

145. Yuan A, Kumar A, Peterhoff C, Duff K, Nixon RA. Axonal transport rates in vivo are unaffected by tau deletion or overexpression in mice. J Neurosci. 2008; 28:1682-7. [PubMed: 18272688]

146. Griffith LM, Pollard TD. Evidence for actin filament-microtubule interaction mediated by microtubule-associated proteins. J Cell Biol. 1978; 78:958-65. [PubMed: 568144]

147. Griffith LM, Pollard TD. The interaction of actin filaments with microtubules and microtubuleassociated proteins. J Biol Chem. 1982; 257:9143-51. [PubMed: 6124545]

148. Correas I, Padilla R, Avila J. The tubulin-binding sequence of brain microtubule-associated proteins, tau and MAP-2, is also involved in actin binding. Biochem J. 1990; 269:61-4. [PubMed: 2115775]

149. Moraga DM, Nunez P, Garrido J, Maccioni RB. A tau fragment containing a repetitive sequence induces bundling of actin filaments. J Neurochem. 1993; 61:979-86. [PubMed: 8360695]

150. DiTella M, Feiguin F, Morfini G, Caceres A. Microfilament-associated growth cone component depends upon Tau for its intracellular localization. Cell Motil Cytoskeleton. 1994; 29:117-30. [PubMed: 7820862]

151. Liu CW, Lee G, Jay DG. Tau is required for neurite outgrowth and growth cone motility of chick sensory neurons. Cell Motil Cytoskel. 1999; 43:232-42.

152. Yu JZ, Rasenick MM. Tau associates with actin in differentiating PC12 cells. Faseb J. 2006; 20:1452-61. [PubMed: 16816120]

153. Roger B, Al-Bassam J, Dehmelt L, Milligan RA, Halpain S. MAP2c, but not tau, binds and bundles F-actin via its microtubule binding domain. Curr Biol. 2004; 14:363-71. [PubMed: 15028210]

154. Biernat J, Wu YZ, Timm T, Zheng-Fischhofer Q, Mandelkow E, Meijer L, Mandelkow EM. Protein kinase MARK/PAR-1 is required for neurite outgrowth and establishment of neuronal polarity. Molecular Biology of the Cell. 2002; 13:4013-28. [PubMed: 12429843]

155. Sharma VM, Litersky JM, Bhaskar K, Lee G. Tau impacts on growth-factor-stimulated actin remodeling. J Cell Sci. 2007; 120:748-57. [PubMed: 17284520]

156. Brandt R, Leger J, Lee G. Interaction of tau with the neural plasma membrane mediated by tau's amino-terminal projection domain. J Cell Biol. 1995; 131:1327-40. [PubMed: 8522593] 
157. Black MM, Slaughter T, Moshiach S, Obrocka M, Fischer I. Tau is enriched on dynamic microtubules in the distal region of growing axons. J Neurosci. 1996; 16:3601-3619. [PubMed: 8642405]

158. Fulga TA, Elson-Schwab I, Khurana V, Steinhilb ML, Spires TL, Hyman BT, Feany MB. Abnormal bundling and accumulation of F-actin mediates tau-induced neuronal degeneration in vivo. Nat Cell Biol. 2007; 9:139-48. [PubMed: 17187063]

159. Minamide LS, Striegl AM, Boyle JA, Meberg PJ, Bamburg JR. Neurodegenerative stimuli induce persistent ADF/cofilin-actin rods that disrupt distal neurite function. Nat Cell Biol. 2000; 2:62836. [PubMed: 10980704]

160. Morishima-Kawashima M, Hasegawa M, Takio K, Suzuki M, Yoshida H, Titani K, Ihara Y. Proline-directed and non-proline-directed phosphorylation of PHF-tau. J Biol Chem. 1995; 270:823-9. [PubMed: 7822317]

161. Yu Y, Run X, Liang Z, Li Y, Liu F, Liu Y, Iqbal K, Grundke-Iqbal I, Gong CX. Developmental regulation of tau phosphorylation, tau kinases, and tau phosphatases. J Neurochem. 2009; 108:1480-94. [PubMed: 19183272]

162. Seubert P, Mawal-Dewan M, Barbour R, Jakes R, Goedert M, Johnson GV, Litersky JM, Schenk D, Lieberburg I, Trojanowski JQ, et al. Detection of phosphorylated Ser262 in fetal tau, adult tau, and paired helical filament tau. Journal of Biological Chemistry. 1995; 270:18917-22. [PubMed: 7642549]

163. Hagestedt T, Lichtenberg B, Wille H, Mandelkow EM, Mandelkow E. Tau protein becomes long and stiff upon phosphorylation: correlation between paracrystalline structure and degree of phosphorylation. J Cell Biol. 1989; 109:1643-51. [PubMed: 2507554]

164. Jeganathan S, Hascher A, Chinnathambi S, Biernat J, Mandelkow EM, Mandelkow E. Prolinedirected pseudo-phosphorylation at AT8 and PHF1 epitopes induces a compaction of the paperclip folding of Tau and generates a pathological (MC-1) conformation. J Biol Chem. 2008; 283:32066-76. [PubMed: 18725412]

165. Guillozet-Bongaarts AL, Cahill ME, Cryns VL, Reynolds MR, Berry RW, Binder LI. Pseudophosphorylation of tau at serine 422 inhibits caspase cleavage: in vitro evidence and implications for tangle formation in vivo. J Neurochem. 2006; 97:1005-14. [PubMed: 16606369]

166. Sengupta A, Wu Q, Grundke-Iqbal I, Iqbal K, Singh TJ. Potentiation of GSK-3-catalyzed Alzheimer-like phosphorylation of human tau by cdk5. Mol Cell Biochem. 1997; 167:99-105. [PubMed: 9059986]

167. Alonso Adel C, Mederlyova A, Novak M, Grundke-Iqbal I, Iqbal K. Promotion of hyperphosphorylation by frontotemporal dementia tau mutations. J Biol Chem. 2004; 279:34873-81. [PubMed: 15190058]

168. Busciglio J, Lorenzo A, Yeh J, Yankner BA. $\beta$-amyloid fibrils induce tau phosphorylation and loss of microtubule binding. Neuron. 1995; 14:879-88. [PubMed: 7718249]

169. Takashima A, Noguchi K, Michel G, Mercken M, Hoshi M, Ishiguro K, Imahori K. Exposure of rat hippocampal neurons to amyloid beta peptide (25-35) induces the inactivation of phosphatidyl inositol-3 kinase and the activation of tau protein kinase I/glycogen synthase kinase-3 beta. Neurosci Lett. 1996; 203:33-6. [PubMed: 8742040]

170. Rapoport M, Ferreira A. PD98059 prevents neurite degeneration induced by fibrillar betaamyloid in mature hippocampal neurons. J Neurochem. 2000; 74:125-33. [PubMed: 10617113]

171. Matsuo ES, Shin RW, Billingsley ML, Van deVoorde A, O'Connor M, Trojanowski JQ, Lee VM. Biopsy-derived adult human brain tau is phosphorylated at many of the same sites as Alzheimer's disease paired helical filament tau. Neuron. 1994; 13:989-1002. [PubMed: 7946342]

172. Sontag E, Nunbhakdi-Craig V, Lee G, Bloom GS, Mumby MC. Regulation of the phosphorylation state and microtubule-binding activity of Tau by protein phosphatase $2 \mathrm{~A}$. Neuron. 1996; 17:1201-7. [PubMed: 8982166]

173. Sontag E, Nunbhakdi-Craig V, Lee G, Brandt R, Kamibayashi C, Kuret J, White CL 3rd, Mumby $\mathrm{MC}$, Bloom GS. Molecular interactions among protein phosphatase 2A, tau, and microtubules. Implications for the regulation of tau phosphorylation and the development of tauopathies. J Biol Chem. 1999; 274:25490-8. [PubMed: 10464280] 
174. Liao H, Li Y, Brautigan DL, Gundersen GG. Protein phosphatase 1 is targeted to microtubules by the microtubule-associated protein Tau. J Biol Chem. 1998; 273:21901-8. [PubMed: 9705329]

175. Rahman A, Grundke-Iqbal I, Iqbal K. Phosphothreonine-212 of Alzheimer abnormally hyperphosphorylated tau is a preferred substrate of protein phosphatase-1. Neurochem Res. 2005; 30:277-87. [PubMed: 15895832]

176. Liu F, Grundke-Iqbal I, Iqbal K, Gong CX. Contributions of protein phosphatases PP1, PP2A, PP2B and PP5 to the regulation of tau phosphorylation. Eur J Neurosci. 2005; 22:1942-50. [PubMed: 16262633]

177. Goedert M, Satumtira S, Jakes R, Smith MJ, Kamibayashi C, White CL 3rd, Sontag E. Reduced binding of protein phosphatase $2 \mathrm{~A}$ to tau protein with frontotemporal dementia and parkinsonism linked to chromosome 17 mutations. J Neurochem. 2000; 75:2155-62. [PubMed: 11032905]

178. Lee G, Newman ST, Gard DL, Band H, Panchamoorthy G. Tau interacts with src-family nonreceptor tyrosine kinases. J Cell Sci. 1998; 111 (Pt 21):3167-77. [PubMed: 9763511]

179. Derkinderen P, Scales TM, Hanger DP, Leung KY, Byers HL, Ward MA, Lenz C, Price C, Bird IN, Perera T, Kellie S, Williamson R, Noble W, Van Etten RA, Leroy K, Brion JP, Reynolds CH, Anderton BH. Tyrosine 394 is phosphorylated in Alzheimer's paired helical filament tau and in fetal tau with cAbl as the candidate tyrosine kinase. J Neurosci. 2005; 25:6584-93. [PubMed: 16014719]

180. Lebouvier T, Scales TM, Hanger DP, Geahlen RL, Lardeux B, Reynolds CH, Anderton BH, Derkinderen P. The microtubule-associated protein tau is phosphorylated by Syk. Biochim Biophys Acta. 2008; 1783:188-92. [PubMed: 18070606]

181. Lee G, Thangavel R, Sharma VM, Litersky JM, Bhaskar K, Fang SM, Do LH, Andreadis A, Van Hoesen G, Ksiezak-Reding H. Phosphorylation of tau by fyn: implications for Alzheimer's disease. J Neurosci. 2004; 24:2304-12. [PubMed: 14999081]

182. Vega IE, Cui L, Propst JA, Hutton ML, Lee G, Yen SH. Increase in tau tyrosine phosphorylation correlates with the formation of tau aggregates. Brain Res Mol Brain Res. 2005; 138:135-44. [PubMed: 15913839]

183. Bhaskar K, Hobbs GA, Yen SH, Lee G. Tyrosine phosphorylation of tau accompanies disease progression in transgenic mouse models of tauopathy. Neuropathol Appl Neurobiol. 2010; 36:462-77. [PubMed: 20609109]

184. Sato S, Cerny RL, Buescher JL, Ikezu T. Tau-tubulin kinase 1 (TTBK1), a neuron-specific tau kinase candidate, is involved in tau phosphorylation and aggregation. J Neurochem. 2006; 98:1573-84. [PubMed: 16923168]

185. Williamson R, Scales T, Clark BR, Gibb G, Reynolds CH, Kellie S, Bird IN, Varndell IM, Sheppard PW, Everall I, Anderton BH. Rapid tyrosine phosphorylation of neuronal proteins including tau and focal adhesion kinase in response to amyloid-beta peptide exposure: involvement of Src family protein kinases. J Neurosci. 2002; 22:10-20. [PubMed: 11756483]

186. Chin J, Palop JJ, Yu GQ, Kojima N, Masliah E, Mucke L. Fyn kinase modulates synaptotoxicity, but not aberrant sprouting, in human amyloid precursor protein transgenic mice. Journal of Neuroscience. 2004; 24:4692-7. [PubMed: 15140940]

187. Lambert MP, Barlow AK, Chromy BA, Edwards C, Freed R, Liosatos M, Morgan TE, Rozovsky I, Trommer B, Viola KL, Wals P, Zhang C, Finch CE, Krafft GA, Klein WL. Diffusible, nonfibrillar ligands derived from Abeta1-42 are potent central nervous system neurotoxins. Proc Natl Acad Sci U S A. 1998; 95:6448-53. [PubMed: 9600986]

188. Ho GJ, Hashimoto M, Adame A, Izu M, Alford MF, Thal LJ, Hansen LA, Masliah E. Altered p59Fyn kinase expression accompanies disease progression in Alzheimer's disease: implications for its functional role. Neurobiol Aging. 2005; 26:625-35. [PubMed: 15708437]

189. Arnold CS, Johnson GV, Cole RN, Dong DL, Lee M, Hart GW. The microtubule-associated protein tau is extensively modified with O-linked N-acetylglucosamine. J Biol Chem. 1996; 271:28741-4. [PubMed: 8910513]

190. Liu F, Iqbal K, Grundke-Iqbal I, Gong CX. Involvement of aberrant glycosylation in phosphorylation of tau by cdk5 and GSK-3beta. FEBS Lett. 2002; 530:209-14. [PubMed: 12387894] 
191. Reynolds MR, Reyes JF, Fu Y, Bigio EH, Guillozet-Bongaarts AL, Berry RW, Binder LI. Tau nitration occurs at tyrosine 29 in the fibrillar lesions of Alzheimer's disease and other tauopathies. J Neurosci. 2006; 26:10636-45. [PubMed: 17050703]

192. Petrucelli L, Dickson D, Kehoe K, Taylor J, Snyder H, Grover A, De Lucia M, McGowan E, Lewis J, Prihar G, Kim J, Dillmann WH, Browne SE, Hall A, Voellmy R, Tsuboi Y, Dawson TM, Wolozin B, Hardy J, Hutton M. CHIP and Hsp70 regulate tau ubiquitination, degradation and aggregation. Hum Mol Genet. 2004; 13:703-14. [PubMed: 14962978]

193. Shimura H, Schwartz D, Gygi SP, Kosik KS. CHIP-Hsc70 complex ubiquitinates phosphorylated tau and enhances cell survival. J Biol Chem. 2004; 279:4869-76. [PubMed: 14612456]

194. Hatakeyama S, Matsumoto M, Kamura T, Murayama M, Chui DH, Planel E, Takahashi R, Nakayama KI, Takashima A. U-box protein carboxyl terminus of Hsc70-interacting protein (CHIP) mediates poly-ubiquitylation preferentially on four-repeat Tau and is involved in neurodegeneration of tauopathy. J Neurochem. 2004; 91:299-307. [PubMed: 15447663]

195. Morishima-Kawashima M, Hasegawa M, Takio K, Suzuki M, Titani K, Ihara Y. Ubiquitin is conjugated with amino-terminally processed tau in paired helical filaments. Neuron. 1993; 10:1151-60. [PubMed: 8391280]

196. Cripps D, Thomas SN, Jeng Y, Yang F, Davies P, Yang AJ. Alzheimer disease-specific conformation of hyperphosphorylated paired helical filament-Tau is polyubiquitinated through Lys-48, Lys-11, and Lys-6 ubiquitin conjugation. J Biol Chem. 2006; 281:10825-38. [PubMed: 16443603]

197. Dickey CA, Yue M, Lin WL, Dickson DW, Dunmore JH, Lee WC, Zehr C, West G, Cao S, Clark AM, Caldwell GA, Caldwell KA, Eckman C, Patterson C, Hutton M, Petrucelli L. Deletion of the ubiquitin ligase CHIP leads to the accumulation, but not the aggregation, of both endogenous phospho- and caspase-3-cleaved tau species. J Neurosci. 2006; 26:6985-96. [PubMed: 16807328]

198. Dorval V, Fraser PE. Small ubiquitin-like modifier (SUMO) modification of natively unfolded proteins tau and alpha-synuclein. J Biol Chem. 2006; 281:9919-24. [PubMed: 16464864]

199. Lu PJ, Wulf G, Zhou XZ, Davies P, Lu KP. The prolyl isomerase Pin1 restores the function of Alzheimer-associated phosphorylated tau protein. Nature. 1999; 399:784-8. [PubMed: 10391244]

200. Smet C, Sambo AV, Wieruszeski JM, Leroy A, Landrieu I, Buee L, Lippens G. The peptidyl prolyl cis/trans-isomerase Pin1 recognizes the phospho-Thr212-Pro213 site on Tau. Biochemistry. 2004; 43:2032-40. [PubMed: 14967043]

201. Lim J, Balastik M, Lee TH, Nakamura K, Liou YC, Sun A, Finn G, Pastorino L, Lee VM, Lu KP. Pin1 has opposite effects on wild-type and P301L tau stability and tauopathy. J Clin Invest. 2008; 118:1877-89. [PubMed: 18431510]

202. Yotsumoto K, Saito T, Asada A, Oikawa T, Kimura T, Uchida C, Ishiguro K, Uchida T, Hasegawa M, Hisanaga S. Effect of Pin1 or Microtubule Binding on Dephosphorylation of FTDP-17 Mutant Tau. J Biol Chem. 2009; 284:16840-7. [PubMed: 19401603]

203. Zhou XZ, Kops O, Werner A, Lu PJ, Shen M, Stoller G, Kullertz G, Stark M, Fischer G, Lu KP. Pin1-dependent prolyl isomerization regulates dephosphorylation of $\mathrm{Cdc} 25 \mathrm{C}$ and tau proteins. Mol Cell. 2000; 6:873-83. [PubMed: 11090625]

204. Liou YC, Sun A, Ryo A, Zhou XZ, Yu ZX, Huang HK, Uchida T, Bronson R, Bing G, Li X, Hunter T, Lu KP. Role of the prolyl isomerase Pin1 in protecting against age-dependent neurodegeneration. Nature. 2003; 424:556-61. [PubMed: 12891359]

205. Hashiguchi M, Sobue K, Paudel HK. 14-3-3zeta is an effector of tau protein phosphorylation. J Biol Chem. 2000; 275:25247-54. [PubMed: 10840038]

206. Hernandez F, Cuadros R, Avila J. Zeta 14-3-3 protein favours the formation of human tau fibrillar polymers. Neurosci Lett. 2004; 357:143-6. [PubMed: 15036595]

207. Agarwal-Mawal A, Qureshi HY, Cafferty PW, Yuan Z, Han D, Lin R, Paudel HK. 14-3-3 connects glycogen synthase kinase-3 beta to tau within a brain microtubule-associated tau phosphorylation complex. J Biol Chem. 2003; 278:12722-8. [PubMed: 12551948]

208. Matthews TA, Johnson GV. 14-3-3Zeta does not increase GSK3beta-mediated tau phosphorylation in cell culture models. Neurosci Lett. 2005; 384:211-6. [PubMed: 15963640] 
209. Li T, Paudel HK. 14-3-3zeta facilitates GSK3beta-catalyzed tau phosphorylation in HEK-293 cells by a mechanism that requires phosphorylation of GSK3beta on Ser9. Neurosci Lett. 2007; 414:203-8. [PubMed: 17317006]

210. Sadik G, Tanaka T, Kato K, Yamamori H, Nessa BN, Morihara T, Takeda M. Phosphorylation of tau at Ser214 mediates its interaction with 14-3-3 protein: implications for the mechanism of tau aggregation. J Neurochem. 2009; 108:33-43. [PubMed: 19014373]

211. Sluchanko NN, Seit-Nebi AS, Gusev NB. Phosphorylation of more than one site is required for tight interaction of human tau protein with 14-3-3zeta. FEBS Lett. 2009; 583:2739-42. [PubMed: 19647741]

212. Sadik G, Tanaka T, Kato K, Yanagi K, Kudo T, Takeda M. Differential interaction and aggregation of 3-repeat and 4-repeat tau isoforms with 14-3-3zeta protein. Biochem Biophys Res Commun. 2009; 383:37-41. [PubMed: 19324008]

213. Leugers CJ, Lee G. Tau potentiates nerve growth factor-induced mitogen-activated protein kinase signaling and neurite initiation without a requirement for microtubule binding. J Biol Chem. 2010; 285:19125-34. [PubMed: 20375017]

214. Hasegawa M, Morishima-Kawashima M, Takio K, Suzuki M, Titani K, Ihara Y. Protein sequence and mass spectrometric analyses of tau in the Alzheimer's disease brain. J Biol Chem. 1992; 267:17047-54. [PubMed: 1512244]

215. Vincent I, Zheng JH, Dickson DW, Kress Y, Davies P. Mitotic phosphoepitopes precede paired helical filaments in Alzheimer's disease. Neurobiol Aging. 1998; 19:287-96. [PubMed: 9733160]

216. Pei JJ, Braak H, An WL, Winblad B, Cowburn RF, Iqbal K, Grundke-Iqbal I. Up-regulation of mitogen-activated protein kinases ERK1/2 and MEK1/2 is associated with the progression of neurofibrillary degeneration in Alzheimer's disease. Brain Res Mol Brain Res. 2002; 109:45-55. [PubMed: 12531514]

217. Ferrer I, Blanco R, Carmona M, Ribera R, Goutan E, Puig B, Rey MJ, Cardozo A, Vinals F, Ribalta T. Phosphorylated map kinase (ERK1, ERK2) expression is associated with early tau deposition in neurones and glial cells, but not with increased nuclear DNA vulnerability and cell death, in Alzheimer disease, Pick's disease, progressive supranuclear palsy and corticobasal degeneration. Brain Pathol. 2001; 11:144-58. [PubMed: 11303790]

218. Perry G, Roder H, Nunomura A, Takeda A, Friedlich AL, Zhu X, Raina AK, Holbrook N, Siedlak SL, Harris PL, Smith MA. Activation of neuronal extracellular receptor kinase (ERK) in Alzheimer disease links oxidative stress to abnormal phosphorylation. Neuroreport. 1999; 10:2411-5. [PubMed: 10439473]

219. Reynolds CH, Garwood CJ, Wray S, Price C, Kellie S, Perera T, Zvelebil M, Yang A, Sheppard PW, Varndell IM, Hanger DP, Anderton BH. Phosphorylation regulates tau interactions with Src homology 3 domains of phosphatidylinositol 3-kinase, phospholipase Cgamma1, Grb2, and Src family kinases. J Biol Chem. 2008; 283:18177-86. [PubMed: 18467332]

220. Jenkins SM, Johnson GV. Tau complexes with phospholipase C-gamma in situ. Neuroreport. 1998; 9:67-71. [PubMed: 9592050]

221. Hwang SC, Jhon DY, Bae YS, Kim JH, Rhee SG. Activation of phospholipase C-gamma by the concerted action of tau proteins and arachidonic acid. J Biol Chem. 1996; 271:18342-9. [PubMed: 8702475]

222. Bhaskar K, Yen SH, Lee G. Disease-related modifications in tau affect the interaction between Fyn and Tau. J Biol Chem. 2005; 280:35119-25. [PubMed: 16115884]

223. Zamora-Leon SP, Lee G, Davies P, Shafit-Zagardo B. Binding of Fyn to MAP-2c through an SH3 binding domain. Regulation of the interaction by ERK2. Journal of Biological Chemistry. 2001; 276:39950-8. [PubMed: 11546790]

224. Sarkar M, Kuret J, Lee G. Two motifs within the tau microtubule-binding domain mediate its association with the hsc70 molecular chaperone. J Neurosci Res. 2008; 86:2763-73. [PubMed: 18500754]

225. Elliott E, Tsvetkov P, Ginzburg I. BAG-1 associates with Hsc70.Tau complex and regulates the proteasomal degradation of Tau protein. J Biol Chem. 2007; 282:37276-84. [PubMed: 17954934] 
226. Wang Y, Martinez-Vicente M, Kruger U, Kaushik S, Wong E, Mandelkow EM, Cuervo AM, Mandelkow E. Tau fragmentation, aggregation and clearance: the dual role of lysosomal processing. Hum Mol Genet. 2009; 18:4153-70. [PubMed: 19654187]

227. Dolan PJ, Johnson GV. A caspase cleaved form of tau is preferentially degraded through the autophagy pathway. J Biol Chem. 2010; 285:21978-87. [PubMed: 20466727]

228. Dickey CA, Dunmore J, Lu B, Wang JW, Lee WC, Kamal A, Burrows F, Eckman C, Hutton M, Petrucelli L. HSP induction mediates selective clearance of tau phosphorylated at prolinedirected Ser/Thr sites but not KXGS (MARK) sites. Faseb J. 2006; 20:753-5. [PubMed: 16464956]

229. Dickey CA, Kamal A, Lundgren K, Klosak N, Bailey RM, Dunmore J, Ash P, Shoraka S, Zlatkovic J, Eckman CB, Patterson C, Dickson DW, Nahman NS Jr, Hutton M, Burrows F, Petrucelli L. The high-affinity HSP90-CHIP complex recognizes and selectively degrades phosphorylated tau client proteins. J Clin Invest. 2007; 117:648-58. [PubMed: 17304350]

230. Sahara N, Maeda S, Yoshiike Y, Mizoroki T, Yamashita S, Murayama M, Park JM, Saito Y, Murayama S, Takashima A. Molecular chaperone-mediated tau protein metabolism counteracts the formation of granular tau oligomers in human brain. J Neurosci Res. 2007; 85:3098-108. [PubMed: 17628496]

231. Loomis PA, Howard TH, Castleberry RP, Binder LI. Identification of nuclear tau isoforms in human neuroblastoma cells. Proc Natl Acad Sci U S A. 1990; 87:8422-6. [PubMed: 1700432]

232. Thurston VC, Zinkowski RP, Binder LI. Tau as a nucleolar protein in human nonneural cells in vitro and in vivo. Chromosoma. 1996; 105:20-30. [PubMed: 8662255]

233. Papasozomenos SC, Binder LI. Phosphorylation determines two distinct species of Tau in the central nervous system. Cell Motil Cytoskeleton. 1987; 8:210-26. [PubMed: 2446784]

234. Lefebvre T, Ferreira S, Dupont-Wallois L, Bussiere T, Dupire MJ, Delacourte A, Michalski JC, Caillet-Boudin ML. Evidence of a balance between phosphorylation and O-GlcNAc glycosylation of Tau proteins--a role in nuclear localization. Biochim Biophys Acta. 2003; 1619:167-76. [PubMed: 12527113]

235. Krylova SM, Musheev M, Nutiu R, Li Y, Lee G, Krylov SN. Tau protein binds single-stranded DNA sequence specifically--the proof obtained in vitro with non-equilibrium capillary electrophoresis of equilibrium mixtures. FEBS Lett. 2005; 579:1371-5. [PubMed: 15733843]

236. Rossi G, Dalpra L, Crosti F, Lissoni S, Sciacca FL, Catania M, Di Fede G, Mangieri M, Giaccone G, Croci D, Tagliavini F. A new function of microtubule-associated protein tau: involvement in chromosome stability. Cell Cycle. 2008; 7:1788-94. [PubMed: 18583940]

237. Maas T, Eidenmuller J, Brandt R. Interaction of tau with the neural membrane cortex is regulated by phosphorylation at sites that are modified in paired helical filaments. J Biol Chem. 2000; 275:15733-40. [PubMed: 10747907]

238. Arrasate M, Perez M, Avila J. Tau dephosphorylation at tau-1 site correlates with its association to cell membrane. Neurochem Res. 2000; 25:43-50. [PubMed: 10685603]

239. Mandell JW, Banker GA. A spatial gradient of tau protein phosphorylation in nascent axons. J Neurosci. 1996; 16:5727-40. [PubMed: 8795628]

240. Klein C, Kramer EM, Cardine AM, Schraven B, Brandt R, Trotter J. Process outgrowth of oligodendrocytes is promoted by interaction of fyn kinase with the cytoskeletal protein tau. $\mathrm{J}$ Neurosci. 2002; 22:698-707. [PubMed: 11826099]

241. Kawarabayashi T, Shoji M, Younkin LH, Wen-Lang L, Dickson DW, Murakami T, Matsubara E, Abe K, Ashe KH, Younkin SG. Dimeric amyloid beta protein rapidly accumulates in lipid rafts followed by apolipoprotein $\mathrm{E}$ and phosphorylated tau accumulation in the $\mathrm{Tg} 2576$ mouse model of Alzheimer's disease. J Neurosci. 2004; 24:3801-9. [PubMed: 15084661]

242. Williamson R, Usardi A, Hanger DP, Anderton BH. Membrane-bound beta-amyloid oligomers are recruited into lipid rafts by a fyn-dependent mechanism. Faseb J. 2008; 22:1552-9. [PubMed: 18096814]

243. Hernandez P, Lee G, Sjoberg M, Maccioni RB. Tau phosphorylation by cdk5 and Fyn in response to amyloid peptide Abeta (25-35): involvement of lipid rafts. J Alzheimers Dis. 2009; 16:14956. [PubMed: 19158430] 
244. Kim WH, Lee S, Jung C, Ahmed A, Lee G, Hall GF. Interneuronal transfer of human tau between lamprey central neurons in situ. J Alzheimers Dis. 2010; 19:647-64. [PubMed: 20110609]

245. Gomez-Ramos A, Diaz-Hernandez M, Rubio A, Miras-Portugal MT, Avila J. Extracellular tau promotes intracellular calcium increase through M1 and M3 muscarinic receptors in neuronal cells. Mol Cell Neurosci. 2008; 37:673-81. [PubMed: 18272392]

246. Clavaguera F, Bolmont T, Crowther RA, Abramowski D, Frank S, Probst A, Fraser G, Stalder AK, Beibel M, Staufenbiel M, Jucker M, Goedert M, Tolnay M. Transmission and spreading of tauopathy in transgenic mouse brain. Nat Cell Biol. 2009; 11:909-13. [PubMed: 19503072]

247. Frost B, Jacks RL, Diamond MI. Propagation of tau misfolding from the outside to the inside of a cell. J Biol Chem. 2009; 284:12845-52. [PubMed: 19282288]

248. Belkadi A, LoPresti P. Truncated Tau with the Fyn-binding domain and without the microtubulebinding domain hinders the myelinating capacity of an oligodendrocyte cell line. J Neurochem. 2008; 107:351-60. [PubMed: 18680553]

249. King ME, Kan HM, Baas PW, Erisir A, Glabe CG, Bloom GS. Tau-dependent microtubule disassembly initiated by prefibrillar beta-amyloid. J Cell Biol. 2006; 175:541-6. [PubMed: 17101697]

250. Ittner LM, Ke YD, Delerue F, Bi M, Gladbach A, van Eersel J, Wolfing H, Chieng BC, Christie MJ, Napier IA, Eckert A, Staufenbiel M, Hardeman E, Gotz J. Dendritic function of tau mediates amyloid-beta toxicity in Alzheimer's disease mouse models. Cell. 2010; 142:387-97. [PubMed: 20655099]

251. Luo MH, Leski ML, Andreadis A. Tau isoforms which contain the domain encoded by exon 6 and their role in neurite elongation. J Cell Biochem. 2004; 91:880-95. [PubMed: 15034924]

252. Park SY, Ferreira A. The generation of a $17 \mathrm{kDa}$ neurotoxic fragment: an alternative mechanism by which tau mediates beta-amyloid-induced neurodegeneration. J Neurosci. 2005; 25:5365-75. [PubMed: 15930385]

253. Nicholson AM, Ferreira A. Increased membrane cholesterol might render mature hippocampal neurons more susceptible to beta-amyloid-induced calpain activation and tau toxicity. J Neurosci. 2009; 29:4640-51. [PubMed: 19357288]

254. Mukrasch MD, Bibow S, Korukottu J, Jeganathan S, Biernat J, Griesinger C, Mandelkow E, Zweckstetter M. Structural polymorphism of 441-residue tau at single residue resolution. PLoS Biol. 2009; 7:e34. [PubMed: 19226187]

255. Pei JJ, Hugon J. mTOR-dependent signalling in Alzheimer's disease. J Cell Mol Med. 2008; 12:2525-32. [PubMed: 19210753]

256. Goedert M, Hasegawa M, Jakes R, Lawler S, Cuenda A, Cohen P. Phosphorylation of microtubule-associated protein tau by stress-activated protein kinases. FEBS Lett. 1997; 409:5762. [PubMed: 9199504]

257. Liu F, Liang Z, Wegiel J, Hwang YW, Iqbal K, Grundke-Iqbal I, Ramakrishna N, Gong CX. Overexpression of Dyrk1A contributes to neurofibrillary degeneration in Down syndrome. Faseb J. 2008; 22:3224-33. [PubMed: 18509201]

258. Reynolds CH, Betts JC, Blackstock WP, Nebreda AR, Anderton BH. Phosphorylation sites on tau identified by nanoelectrospray mass spectrometry: differences in vitro between the mitogenactivated protein kinases ERK2, c-Jun N-terminal kinase and P38, and glycogen synthase kinase-3beta. J Neurochem. 2000; 74:1587-95. [PubMed: 10737616]

259. Ryoo SR, Jeong HK, Radnaabazar C, Yoo JJ, Cho HJ, Lee HW, Kim IS, Cheon YH, Ahn YS, Chung SH, Song WJ. DYRK1A-mediated hyperphosphorylation of Tau. A functional link between Down syndrome and Alzheimer disease. J Biol Chem. 2007; 282:34850-7. [PubMed: 17906291]

260. Shahani N, Brandt R. Functions and malfunctions of the tau proteins. Cell Mol Life Sci. 2002; 59:1668-80. [PubMed: 12475178]

261. Carmel G, Mager EM, Binder LI, Kuret J. The structural basis of monoclonal antibody Alz50's selectivity for Alzheimer's disease pathology. J Biol Chem. 1996; 271:32789-95. [PubMed: 8955115] 
262. Horowitz PM, Patterson KR, Guillozet-Bongaarts AL, Reynolds MR, Carroll CA, Weintraub ST, Bennett DA, Cryns VL, Berry RW, Binder LI. Early N-terminal changes and caspase- 6 cleavage of tau in Alzheimer's disease. J Neurosci. 2004; 24:7895-902. [PubMed: 15356202]

263. Kosik KS, Orecchio LD, Binder L, Trojanowski JQ, Lee VM, Lee G. Epitopes that span the tau molecule are shared with paired helical filaments. Neuron. 1988; 1:817-25. [PubMed: 2483104]

264. Mercken M, Vandermeeren M, Lubke U, Six J, Boons J, Van de Voorde A, Martin JJ, Gheuens J. Monoclonal antibodies with selective specificity for Alzheimer Tau are directed against phosphatase-sensitive epitopes. Acta Neuropathol. 1992; 84:265-72. [PubMed: 1384266]

265. Jicha GA, Weaver C, Lane E, Vianna C, Kress Y, Rockwood J, Davies P. cAMP-dependent protein kinase phosphorylations on tau in Alzheimer's disease. J Neurosci. 1999; 19:7486-94. [PubMed: 10460255]

266. Goedert M, Jakes R, Crowther RA, Cohen P, Vanmechelen E, Vandermeeren M, Cras P. Epitope mapping of monoclonal antibodies to the paired helical filaments of Alzheimer's disease: identification of phosphorylation sites in tau protein. Biochem J. 1994; 301 (Pt 3):871-7. [PubMed: 7519852]

267. Weaver CL, Espinoza M, Kress Y, Davies P. Conformational change as one of the earliest alterations of tau in Alzheimer's disease. Neurobiol Aging. 2000; 21:719-27. [PubMed: 11016541]

268. Jicha GA, Lane E, Vincent I, Otvos L Jr, Hoffmann R, Davies P. A conformation- and phosphorylation-dependent antibody recognizing the paired helical filaments of Alzheimer's disease. J Neurochem. 1997; 69:2087-95. [PubMed: 9349554]

269. Otvos L Jr, Feiner L, Lang E, Szendrei GI, Goedert M, Lee VM. Monoclonal antibody PHF-1 recognizes tau protein phosphorylated at serine residues 396 and 404. J Neurosci Res. 1994; 39:669-73. [PubMed: 7534834] 


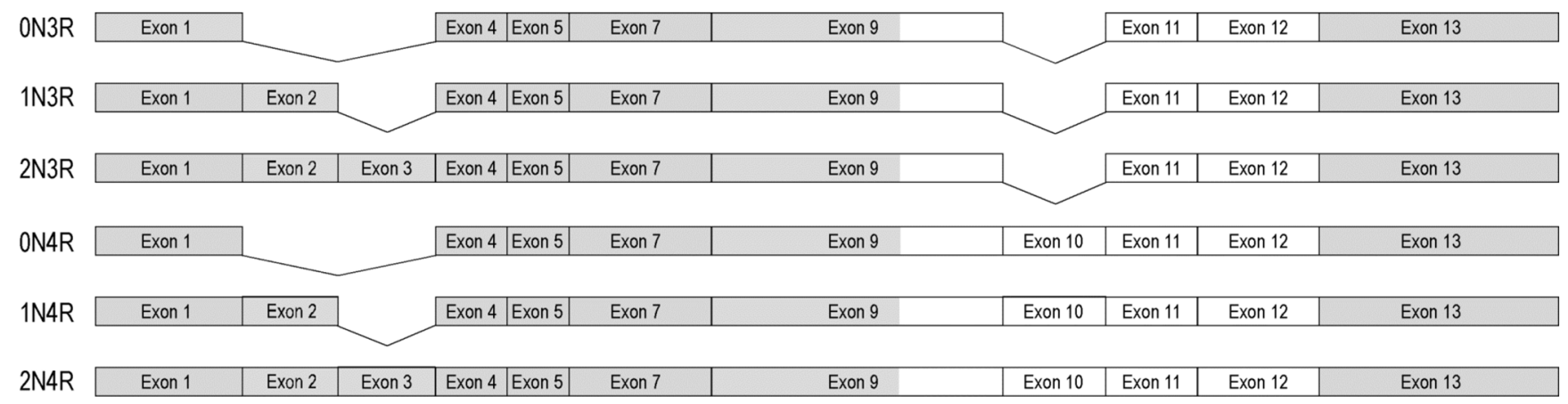

Fig. 1.

Tau schematic, drawn to scale, showing the six tau isoforms present in human brain. Exons 2,3 , and 10 are only expressed in the adult. Clear areas each contain a microtubule binding motif (e.g., exon 10-containing isoforms contain four microtubule binding motifs). 


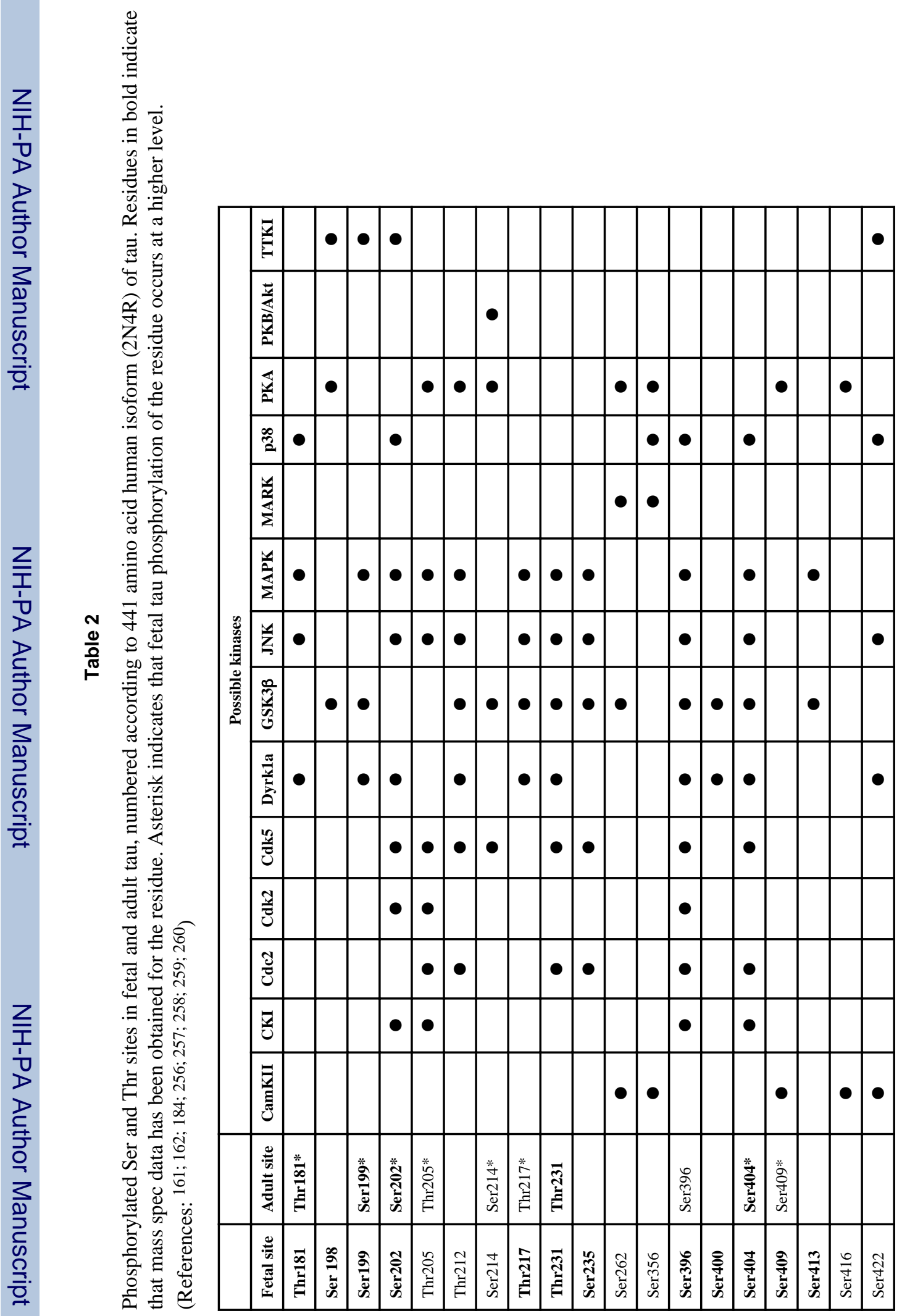


Table 3

Monoclonal tau antibodies (others are also available) Polyclonal antibodies are also commercially available.

\begin{tabular}{|l|l|l|}
\hline Name & Epitope & Notes \\
\hline Alz50 & Involves amino terminus and MTBR & Conformation specific ${ }^{261}$ \\
\hline Tau12 & Amino acids 9-18 & Human specific, total tau ${ }^{262}$ \\
\hline Tau1 & Amino acids 189-207 & Dephosphorylation specific 263 \\
\hline Tau5 & Amino acids 210-230 & Total tau, rodent $>$ human 261 \\
\hline AT8 & Phospho-Ser202/Ser205 & 264 \\
\hline CP13 & Phospho-Ser202 & 265 \\
\hline AT100 & Phospho-Thr212/Ser214 & \\
\hline CP3 & Phospho-Ser214 & 265 \\
\hline AT180 & Phospho-Thr231 & 266 \\
\hline CP17 & Phospho-Thr231 & 267 \\
\hline TG3 & Phospho-Thr231 & Conformation specific 68 \\
\hline CP9 & Phospho-Thr231 & 265 \\
\hline 12E8 & Phospho-Ser262/Ser356 & 162 \\
\hline PG5 & Phospho-Ser409 & 265 \\
\hline PHF-1 & Phospho-Ser396/Ser404 & 269 \\
\hline 9G3 & Phospho-Tyr18 & 181 \\
\hline
\end{tabular}

